\title{
Minimum Wages in Monopsonistic Labor Markets
}

\author{
Luis F. Munguía Corella \\ UCI and CONASAMI* \\ lfmunguia@uci.edu
}

July 2020

(Working Paper)

\begin{abstract}
$\underline{\text { Abstract }}$
Over the last 30 years, researchers have disputed the mixed evidence of the effect of the minimum wage on teenage employment in the U.S. Whenever the minimum wage has positive or no effects on employment, they appeal to monopsony models to explain their results. However, very few of these studies have empirically tested whether their results are due to monopsonistic characteristics in the labor markets. In this paper, I estimate the effects of the minimum wage for the U.S. under concentrated labor markets and low-mobility jobs (two variables that measure monopsony), identify heterogeneous effects among different scenarios derived from the monopsony model, and provide a plausible explanation of the mixed results about the minimum wage effects in the literature. My main findings indicate that minimum wages have an elasticity to teenage employment of -0.418 under perfect competition, which is, as expected, much higher than the usual results in the literature. If the monopsony variable is one standard deviation higher than the baseline, it implies a positive change in elasticity between of 0.05 . The minimum wage has a positive insignificant effect between 0.04 and 0.29 under full monopsonistic labor markets. The results are consistent among different specifications and controlling for possible external shocks to the monopsony and omitted variables.
\end{abstract}

Keywords: minimum wage, monopsony, labor policy, oligopsony

* Mexican National Commission on Minimum Wages 


\section{Introduction}

Policies that introduce minimum wages are often controversial. An extensive literature has studied the effects of minimum wages on employment. While most of the evidence points toward a negative impact, there is also plenty of new evidence of zero or even positive effects. Theoretically, adverse effects on employment are expected within a competitive labor market. However, under a less competitive market, where firms have monopsony power, wages can be lower than the optimal level, and a minimum wage can have ambiguous effects. The literature has primarily focused on the average effect of the minimum wage on employment. Still, almost no studies have empirically analyzed whether these effects depend on the degree of monopsony in the labor market.

Many studies have used the monopsony model to explain non-negative results, including those conducted by Card and Krueger (1994), Katz and Krueger (1992), Allegretto et al. (2011, 2013), and Dube et al. (2010, 2016). However, none of these mentioned papers empirically test whether their results are due to labor market concentration or monopsony (Neumark, 2019).

There is one exception, namely, a working paper by Aznar et al. (2019), where the authors analyze the effect of minimum wages in three occupations (stock clerks, retail salespeople, and cashiers) in the U.S. They also construct an HHI of employment, and their data comes from the website CareerBuilder.com. They estimate interactions of the minimum wage and HHI. Their results are in line with this paper as well. However, their results are limited to only a few occupations and do not cover all the U.S. counties, while this paper looks at a broader set of occupations and covers all U.S. counties.

What are the effects of minimum wages under monopsonistic labor markets? According to the monopsony model, the effect of a minimum wage is ambiguous if the labor market has monopsonistic characteristics, and outcomes will depend on the level of the minimum wage and 
the supply and demand of each firm. In this model, the effects of the minimum wage depend on the elasticity of labor supply; if the labor supply is inelastic, then the monopsony power is higher, and minimum wages might have positive effects on employment.

I address this question by empirically identifying how the effects of minimum wages depend on the monopsony power of the market, where monopsony is measured by labor market concentration or labor mobility. To measure the degree of concentration, I construct a Herfindahl-Hirschman Index (HHI) that measures the concentration of total industrial employment at a county-cluster-quarter level for the U.S. using the Quarterly Workforce Indicators (QWI). I propose different methods to measure the relevant labor market (in clusters) and its concentration. The QWI is not a survey, but actually it is data from almost all the firms in the U.S. Therefore, it has the advantage that represent most of the universe of the employment in the country, and report data at different industrial levels; hence, it is possible to calculate the concentration by industry. The drawback is that it is not possible to measure the HHI at firm level. To measure labor mobility, I calculate the flows of total workers across industries using the Current Population Survey (CPS). The CPS is a sample of the most representative counties in the U.S., but it has the benefit that it follows workers across time. Thus, it is possible to estimate flows between industries but, as in the case of the HHI, this estimation is only possible at industry level. ${ }^{1}$ In addition, I build clusters of industries for the HHI using the labor mobility of workers. Clusters are created when a certain number of flows of workers between industries are registered. Hence, clusters of industries share a demand of similar labor skills which is more reasonable than assuming that workers can only work in one industry.

\footnotetext{
1 In the main results, I only using flows of workers that did not move to another county (geographical area). However, the results do not change, if I include this group of workers (see Appendix Table A4).
} 
I estimate interactions of the minimum wage and the monopsony variable (HHI or mobility) to separate the effect of the minimum wage on teenage employment depending on the degree of concentration and labor mobility at a county-time level. In all the scenarios, the minimum wage has negative effects in competitive labor markets, and the effect is positive in high concentration or low-mobility counties. In monopsonistic labor markets, increases in minimum wages can be constrained by supply or demand; thus, the effect can be positive or negative. Therefore, I estimate the effect on highly monopsonistic labor markets for different levels of the bindingness of the minimum wage. I measure the level of bindingness with the share of the minimum wage relative to the county's average in a specific period. The estimation allows me to capture the effect in counties where the minimum wage "bites" the equilibrium wage $^{2}$, in other words, where firms are more likely to be demand constrained.

The results indicate that minimum wages have an elasticity of -0.418 under perfect competition, which is much higher than the usual results in the literature. By contrast, the elasticity for full concentration is $0.04(\mathrm{HHI}=1)$ and 0.293 for low mobility, but neither are significant. The effects are positive for HHI higher than 0.9 . There are only $0.12 \%$ of total teenage workers in counties where the minimum wage has positive effects, but it is also true that in $44.19 \%$ the effects are not significant (see Table 4). The results are consistent across different specifications and with controls for possible external shocks to the HHI. In addition, at full concentration and zero mobility of the workers, the effect on employment is more negative if the minimum wage is more binding, which aligns with the monopsony theory.

This paper's main contributions to the literature are (1) studies the heterogeneous effects of minimum wage in the labor market monopsony power, and (2) identifying the effect

\footnotetext{
2 Assuming that the average wage is a raw proxy for the equilibrium wage.
} 
depending on the equilibrium wage (demand- or supply-constrained). I distinguish different effects depending on how close the minimum wage is to the average wage.

The rest of the paper is organized as follows. Section 2 presents a summary of the literature. Section 3 describes the data. Section 4 explains the construction of the concentration index and the labor mobility variable. Section 5 lays out the identification strategy, which includes the effects of minimum wages on local labor markets with different degrees of monopsony. Section 6 presents the results, and Section 7 concludes.

\section{Literature Review}

This section summarizes the literature on the effects of minimum wages and monopsony in labor markets. I focus on papers that analyze minimum wage effects in concentrated labor markets and industries with monopsony power. For a more extensive review of minimum wage effects on employment, see Neumark (2019) and Dube (2019).

For this review, I sort studies into two groups: (1) theoretical approaches to the impact of minimum wages under a monopsony model, and (2) empirical methods to measure minimum wages' effects under monopsony.

Robinson (1933) proposed the monopsony theory. The model explains how the labor market works when the supply curve is not perfectly elastic, and firms are not wage takers. More recent developments related to this topic are presented in the papers of Bhaskar and To (1999) and Bhaskar et al. (2002), and particularly in Manning (2003). These studies examine how monopsonistic labor markets work and provide detailed explanations of different situations that can arise within them. Monopsony in the labor market can arise through concentration, giving firms higher markups and the power to set the wage level. Monopsonistic behavior also results from frictions and the heterogeneous preferences of the workers. For instance, a reduction in 
wages may not affect employment if there are frictions that hinder workers' ability to change jobs, such as specific laws or contracts. Another example is workers' preference for jobs closer to home, so an increase in wages in remote locations does not affect the labor supply. Note that the friction creates a non-perfectly elastic labor supply curve (as also shown in Card et al., 2018).

In the case of the minimum wage and similar policies, the monopsony model is about not only the supply curve elasticity, but also the equilibrium wage. Manning's (2003) model predicts that the effect of minimum wages is ambiguous under monopsonistic labor markets. There are three possible scenarios: (1) firms are unconstrained because the minimum wage is not binding; (2) firms are supply-constrained, and increases in minimum wages have positive effects on employment, and (3) firms are demand-constrained, and if the minimum wage is high, it has negative effects on employment. Hence, minimum wages have ambiguous effects within monopsonistic labor markets, depending on how high the minimum wage is and the degree of competition. For example, an increase in the minimum wage could have positive effects on employment if the wage is below the wage of perfect competition equilibrium (the supply curve determines the impact), and it could have adverse effects if the wage is higher than the perfect competition equilibrium wage (the demand curve determines the wage). I identify these scenarios by estimating the minimum wage's effects in highly concentrated labor markets for different levels of the minimum wage bindingness.

A few papers have analyzed the effect of minimum wages in less competitive labor markets. Three papers are relevant because they include estimations of the minimum wage effects under monopsony. One is by Neumark and Wascher (1994), who propose an approach to estimating the minimum wage effects on competitive model with two regimes and monopsony model with three regimes. They estimate the effects in a three-regime endogenous switching regression model. Their estimations indicate that a small fraction of the observations 
lie in the supply curve (third regime of the monopsony model), which makes employment increase with a rise in the minimum wage.

The second study is by Wessels (1997), who looks at the specific case of servers in the restaurant industry. Tips are a percentage of the total cost of a meal; therefore, as restaurants hire more servers, marginal revenues per serving fall. Restaurant owners must raise the hourly wage to retain the workforce, which implies that they are facing a rising supply curve of labor. The author proposes a quadratic specification and measures the effects by quartiles using dummy variables to estimate the effect of the minimum wage and to capture the positive and negative part of the impact over the supply and demand curves. He finds that the minimum wage has a positive impact on the linear term and a negative effect on the quadratic term, which is very indirect evidence that the monopsony model predictions apply in the servers' labor market.

A recent working paper by Azar et al. (2019) analyzes the effect of the minimum wage on the employment of stock clerks, retail salespeople, and cashiers. They also construct an HHI of employment, and their data comes from the website CareerBuilder.com. Their approach is similar to the one used in this paper. They estimate interactions of the minimum wage and HHI. Their results are in line with this paper as well: they find that minimum wages have positive effects in concentrated labor markets (elasticity of 0.2). However, their results are limited to only a few occupations and do not cover all the U.S. counties, while this paper looks at a broader set of occupations and covers all U.S. counties.

Finally, it is important to briefly mention that there has been a proliferation of new papers that focus on estimating the effect of monopsony on average wages using labor market concentration as a proxy (Azar et al., 2017; Benmelech et al., 2018; Lipsius, 2018; Rinz, 2018; and Abel et al., 2018). Moreover, other studies have calculated the firm's supply elasticity to measure the effect of monopsony (Falch, 2010; Hirsch et al. 2010; Staiger et al. 2010; Webber, 
2016; Dube et al., 2018). In both approaches, the authors find that monopsony power in the labor market is associated with lower average wages, which is consistent with the results in this paper. However, none analyze the effect on employment, nor interactions with minimum wages.

This paper fills in an important gap in the literature by directly investigating how the effects of minimum wage change with market concentration and labor force mobility. In particular, I estimate the effects of the minimum wage when the labor market is monopsonistic or competitive. I provide estimations of the effects in monopsonistic labor markets depending on the how much the minimum wage bites the equilibrium wage. Unlike Azar et al. (2019), which focuses on a particular sector, I examine all industries in the U.S. I also group similar industries within a county together to allow for workers to change jobs across industries and create a more credible labor market (clusters). Thus, it is a more flexible approach that allows workers to change jobs within industries.

\section{Data}

The U.S. labor market data used comes mainly from two sources: the QWI and the CPS. The QWI data are produced through a partnership between the U.S. Census Bureau and the state Labor Market Information (LMI) offices. It provides a public-use aggregation of the matched employer-employee Longitudinal Employer Household Dynamics (LEHD) database. The data are compiled from administrative records collected by 50 states and the District of Columbia for both jobs and firms. The unit of observation in the QWI is the worker-employer pair. The primary source of information in the microdata is the almost universal employer-reported Unemployment Insurance (U.I.) records, which cover around 98\% of all private-sector jobs. The U.I. records provide details on employment, earnings, industry, and place of work. Data from the Census Bureau are used to either match or impute workers' demographic information. 
Most states entered the QWI program between the late 1990s and the early 2000s. In the 1990 s, fewer than five states were in the program, while 42 states had come online by the 2000s. Therefore, the period of the analysis in the paper is from 2000 to 2016 for every quarter. I use information about employment, earnings, county, and age range. The data in the QWI is presented by industry at different levels of aggregation. The industries are classified using the North America Industry Classification System (NAICS), which is the standard classification of economics activities used by Canada, Mexico, and the U.S. The NAICS groups together economic units that have a similar process of production. It has six levels of aggregation. The first two digits of the code designate the sector, the third designates the subsector, the fourth digit designates the industry group, the fifth digit designates the NAICS industry, and the sixth digit designates the national industry. The QWI presents the employment and earnings by age, race, and sex at the 4-digit level (industry). Hence it is possible to aggregate teenage employment (ages between 14 and 19) at 3-digit level (subsectors).

The QWI and the NAICS allowed me to construct the industrial employment HHI for subsectors by county and quarters. The unit of observation in the QWI is industry, county, and quarters. Once the HHI is estimated, all the data are aggregated at the county level. Aggregation is done following the QWI documentation and weighting the HHI by the total employment in each county-quarter. The analysis and estimations are conducted at the county-quarter level to make the results comparable with other papers that analyze minimum wage effects on teenage employment using the QWI (Allegretto et al., 2013; Dube et al. 2016; Meer and West, 2013; and Thompson, 2009).

The CPS is a voluntary survey of about 60,000 households that are selected each month. In contrast with the QWI, the information of the CPS comes from the households, and it has a monthly frequency; while in the QWI, the data comes from establishments, and it has a quarterly 
frequency. However, the monthly data in the CPS can be aggregated into quarters, and the survey is representative of all the U.S. employment.

The CPS allowed me to estimate the flows of the total workers across industries from 2000 to $2016,{ }^{3}$ making it possible to calculate all the industry switches by worker. These flows are used to calculate the labor mobility between industries and to calculate industrial clusters for the HHI. As in the case of the HHI, the labor mobility is calculated at the industry level, and then, it is aggregated to the county-quarter level.

To construct the HHI and the mobility, I assume that the relevant labor market occurs within a county, since, in the U.S., labor mobility between counties is limited, it has decreased significantly over the past few years, and job flows often occur in the same geographic area (Moretti, 2011; Molloy et al., 2014). According to the CPS, only 21.15\% of the workers moved to a different county during the period of analysis. Thus, in my main estimations I dropped the workers that change their location (county) once they change jobs. However, I present the estimation including all the workers (even if they move to another county) in the Appendix for mobility. The results are similar, the effect of the minimum wage on low labor mobility counties is more positive than in counties with more mobility.

The HHI and the flows between industries are calculated using total employment instead of teenage employment. The reason is that total employment better reflects the monopsony power of each industry. For instance, suppose there are 10 industries but, in the data, teens work at only one of them. The HHI or mobility for all workers is very low but is high for teens. But presumably, teens could work at the other industries. This suggests the HHI or the mobility should be estimated for all workers, not just teens. Nevertheless, for completeness, I added in

\footnotetext{
${ }^{3}$ Households are treated as follows: contacted for four consecutive months, out of sample for the next eight months, back in the sample for the following four months, and then retired from the sample.
} 
the Appendix all the estimations using an $\mathrm{HHI}$ and mobility constructed with teenage employment.

Lastly, I use data from the Census Bureau to calculate the total population and teenage population. These two variables, plus total employment, are used as controls. I utilize the correspondence codes and Vaghul and Zipperer's (2016) minimum wage data set to recover minimum wages by counties.

\section{Measurements of Monopsony}

I construct two measurements of monopsony; one is labor market concentration, and the other the mobility of workers across industries. Labor market concentration is measured with an HHI of the total industrial employment at the county-cluster-period level using the QWI.

Concentration of the labor market is a proxy for monopsony. In concentrated markets, workers have fewer job opportunities. Thus, firms have more monopsony power to set wages. The mobility measures how often workers switch to different industries when they change jobs. Mobility is also a good predictor of monopsony; if there is low mobility among firms, it implies that there are frictions that can result in monopsony power. Theory predicts that wages and employment must be lower in monopsonistic labor markets than in competitive ones, and in the case of polices like the minimum wage, its effect on employment is ambiguous (Manning, 2003).

Note that I am calculating both variables at the industry level, which does not necessarily translate into the same conclusion for concentration and labor mobility at a firm level. This issue is addressed in section 4.3.

Using market concentration (HHI) as a proxy of monopsony aligns with the new research about monopsony effects in the U.S. (Azar et al., 2017; Benmelech et al., 2018; Abel et 
al., 2018; Lipsius, 2018; Rinz, 2018; Aznar et al., 2019). Other studies, such as those by Webber (2016) and Dube et al. (2018), directly estimate the labor supply elasticity to measure monopsony.

Low mobility of workers among firms is likely a proper measurement of monopsony as well. For instance, if workers cannot move freely among jobs (because of lack of job opportunities or the presence of friction, among other factors), then the supply elasticity to the firm is positive, which is the definition of monopsony. I identify flows of workers between different industries, and I calculate the percentage of workers who do not switch industries when they change jobs as a proxy to monopsony.

\subsection{Construction of the HHI for Employment}

In this section, I detail how to calculate the HHI. First, I estimate the HHI at the industry level by calculating how much of the total employment of an industry is taken by one specific cluster. ${ }^{4}$ If an industry in a specific county has very few clusters capturing most of the employment, the HHI is high. The higher the HHI, the higher the monopsony power of the employers in the area. Once I calculate the HHI at industry levels, I estimate the average HHI by county.

Ideally, to measure monopsony correctly, I need to estimate the elasticity of the labor supply to each firm in each geographic area. However, it is difficult to obtain firm-level data and determine the supply elasticity. I explained this shortcoming in greater detail in section 4.3. Another possibility is to use occupations instead of industries to measure the demanded skills in the labor market. One problem is that data on occupations are not compatible with the QWI, but more important is that flows between industries and occupations show that workers more

\footnotetext{
${ }^{4}$ I use total employment instead of teenage employment because it is more relevant for calculating monopsony power. For instance, industries that concentrate teenage employment may have less power to set low wages compared to one that concentrates all the employment. However, I also estimate the results using teenage employment. Results do not change substantially. They are available in the Appendix.
} 
frequently change their occupation than their industrial sector. If workers can change their occupation more easily than their industry, that means that occupation does not measure specific skills accurately, and industry is a better proxy for demanded skills.

I use the QWI to calculate the HHI, and I define the labor market by geographic area and cluster of industries. The data for the industries is presented as a 4-digit NAICS code (industry), and, using data from the CPS, I use flows of workers between industries to define clusters.

One objection to calculate the HHI only with NAICS codes is that it assumes that a worker can only have a job in the same 3-digit NAICS industry. For instance, it is not credible that a restaurant worker cannot find a job in a business within a similar industry, such as a convenience store. Therefore, I use CPS to estimate flows between industries. I follow workers between 2000-2016 to calculate the number of times that a worker switches industry, and I compute all the movement between industries. The flows between industries are used to calculate clusters of industries for the HHI. However, the clusters are created when a certain number of relative flows of workers ${ }^{5}$ between industries are registered. ${ }^{6}$ Thus, if it is common that workers switch between NAICS 4233 (Lumber and Other Construction Materials Merchant Wholesalers) and 3311 (Iron and Steel Mills and Ferroalloy Manufacturing), this forms a new cluster or a new labor market, which consists of the union of both industries. See Figure 1 for more details.

I follow different criteria to calculate the industry clusters. I create a network of industries connected by links, where each industry is a node. I need to restrict the number of relative flows

\footnotetext{
5 The relative flows are the total flows between two or more industries divided by the total employment in the industries connected.

${ }^{6}$ The assumption is that if two or more industries have many flows between each other, they likely demand the same skills in labor, and therefore, they are the same labor market.
} 
to define a link because if I use a small number of relative flows, all the industries became one whole cluster. Thus, I define a link as those relative flows of workers above the mean ${ }^{7}$ between industries in the whole period and all counties. Once a link is defined, I allow that all the industries connected by a link become one cluster. Next, I followed a rule: I only use the top three connections for each industry (i.e. one industry with another three) or any other industry with at least in the $90^{\text {th }}$ percentile of the number of relative flows. This allows me to capture only the most important connections. For instance, the industry 4239 (Miscellaneous Durable Goods Merchant Wholesalers) has more relative flows with 562 (Waste Management and Remediation Services), 2213 (Water, Sewage and Other Systems), and 2123 (Nonmetallic Mineral Mining and Quarrying). However, there are many flows with other industries as well, such as with the industry 4219 (Miscellaneous Durable Goods Wholesalers). Thus, in these cases, I added more industries to the cluster until the next candidate has less than the $90^{\text {th }}$ percentile of the relative flows. Using this classification results in 22 clusters of industries. This is my preferred classification, but to check the robustness of the classification, I define another three classifications (see Appendix B) to make clusters. One flexible classification that allows a cluster to be formed by all the links between industries, one that allows only the top two stronger connections make a cluster, and one that uses the NAICS code to define the labor market (no clusters are formed). All these classifications are tested in the robustness section 6.3.

Once I have defined the labor market into clusters, it is possible to calculate concentration by 3-digit NAICS code (subsector level), area (county) and period (quarters), where the share is

\footnotetext{
${ }^{7}$ I try different cutoffs for the number of relative flows. If I consider nodes with fewer than the mean, it results in one cluster of industries (all the industries are connected). Hence, using the mean of flows can be interpreted as the minimum number of flows needed to have at least two clusters of industries.
} 


$$
S_{i, j, a, t}=\frac{e m p_{i, j, a, t}}{\sum_{i=1}^{N} e m p_{i, j, a, t}}
$$

and emp is the total employment of the cluster (4-digit code) $i$, which is part of cluster $j$, in area $a$ at period $t$. NAICS codes are designed to aggregate from 4-digit to 3-digit; for instance, all the codes below 111 (Crop Production) are related: 1112 is for Vegetable and Melon Farming, and 1113 is for Fruit and Tree Nut Farming. However, in the case of clusters, I create new codes for clusters that are related by the flows of workers. For instance, a created/new code 988 includes two industries, 4851 Urban Transit Systems and 5615 Travel Arrangement and Reservation Services. These two industries are part of different NAICS subsectors (485 and 561 respectively), but for the HHI, I aggregate them into one cluster.

The HHI is aggregated as follows:

$$
H H I_{j, a, t}=\sum_{i=1}^{N} s_{i, j, a, t}^{2}
$$

Once I have the $H H I_{j, a, t}$ at clusters, I calculate the average concentration at the county level using the QWI documentation to aggregate the data.

To contextualize the behavior of the measurements of monopsony, I show the evolution of the different classification of concentration in time. All the HHI have similar patterns: concentration has increased in recent years, and with small declines in 2012 and 2016. Hence, the increase in the HHI may explain why studies using recent data are more often finding nonnegative effects of minimum wages on employment.

Next, I show a map of the U.S. to illustrate the regional differences. Green indicates more competitive labor markets, whereas red indicates the opposite (more concentrated markets). There is much heterogeneity in the U.S. and also within states. In general, however, there are more green areas than red areas. The key is the relative differences between areas. The 
map shows that there is more relative concentration in rural areas than in urban ones. However, this does not mean that changes in the HHI affect more the employment in rural areas.

\subsection{Construction of Labor Mobility}

The second variable is labor mobility between industries. The labor mobility is also estimated at the county level, and I am using the CPS to estimate it. Labor mobility is a good proxy for monopsony: low mobility of workers implies higher monopsony power of the employers.

To calculate labor mobility, I estimate the percentage of workers who do not change industries when they change jobs (equation 4.3). I prefer to calculate it this way so that it can be compared with the HHI. A low mobility=1 means that there is zero mobility of workers out of the industry, which implies high monopsony power.

$$
\text { Labor Mobility }_{i, a, t}=\frac{\text { remained }_{i, a, t}}{\text { remained }_{i, a, t}+\text { moved }_{i, a, t}}
$$

As I mention, I am assuming that the relevant labor market is local, i.e., that the workers stay in the same county when they switch industries. Hence, I dropped all the workers that change their location (county) once they change jobs. However, I also present estimations for mobility including all the workers (even if they move to another county) in the Appendix. The results are very similar.

One possible issue is that low industrial labor mobility does not necessarily translate into low firm labor mobility. An industry can be composed of many competitive firms, in which case the monopsony power of each of them would be very limited. Each worker could look for a job among the many firms without having to transfer to another industry. However, as it is showed in the next section, the industrial labor mobility is actually capturing firm's concentration. 


\subsection{Drawbacks of the Measurements of Monopsony}

The measurements of monopsony have two drawbacks. First, I am not estimating the supply elasticity, which is the best proxy for monopsony. Second, the HHI and the labor mobility are estimated at the industrial level rather than at the firm level.

For the former issue, even if it is true that elasticities are the best proxy of monopsony, its calculation requires more disaggregation of the data. A recent paper by Aznar et al. (in progress $)^{8}$ estimates the relationship between supply elasticity and labor market concentration (measured as an HHI). A higher concentration of employers is negatively associated with supply elasticity, which suggests that concentration is a contributing factor to firm-level wage-setting power. Therefore, I consider that using the HHI is a good proxy for monopsony: It is highly correlated with the labor supply elasticity, and in addition, highly concentrated markets present monopsonistic characteristics.

The second issue is that I do not have firm-level data to construct the HHI and the labor mobility. The HHI calculated here assumes that a high concentration at the 4-digit industry or cluster level implies that the workers in that cluster have very few potential employers: hence, the firm has monopsony power. This assumption may be questionable because a higher concentration in an industry does not necessarily mean that there is a lesser number of firms. The same applies for the labor mobility variable. However, both indexes roughly capture the level of concentration by firm. For instance, the estimated elasticities of wages to the HHI in this paper are very similar to those in the papers by Benmelech et al. (2018), Lipsius (2018), and Rinz (2018), which indicates that the HHI used here is an excellent proxy for the one that is constructed from firm-level data.

\footnotetext{
${ }^{8}$ https://www.aeaweb.org/conference/2019/preliminary/1059, retrieved on November 2 $2^{\text {nd }}, 2019$.
} 
Besides, I can test how well both proxies approximates the real level of concentration of firms by calculating the number of establishments across industries and counties for different degrees of HHI and mobility. ${ }^{9}$ Table 1 shows the average and the median number of firms by some percentiles of the HHI and the mobility.

A high HHI implies that fewer firms are available in the industry-county-time observations: for instance, if the $\mathrm{HHI}=1$, the median of firms is 3.18 , and the mean is 5.38 . In contrast, if the HHI is small ( $5^{\text {th }}$ percentile), the median of firms is 708.59 , and the mean is 2,261.91. These numbers imply that even if the industrial HHI does not precisely measure concentration at the firm level, it is at least highly correlated. For the case of labor mobility, a similar pattern emerges. If the variable is equal to one (which means that there is no mobility among industries), the median of firms is way lower than when there is more mobility.

\section{Empirical Strategy}

I use two approaches to estimate the effect of the minimum wage in monopsonistic labor markets. First, I calculate interactions between the minimum wage and the two measures of monopsony (HHI and labor mobility) using two-way fixed effects (geographic area and time). I estimate the effect on teenage workers because this group of workers has a wage closer to the minimum wage ${ }^{10}$. The difference in the impact of minimum wage on employment between monopsonistic markets and competitive ones must be positive, regardless of whether the firms are demand- or supply-constrained. Thus, I expect a positive sign in the coefficient of the interactions. I estimate most of the results using two-way fixed effects in order to make them

\footnotetext{
${ }^{9}$ I have data on the number of establishments by county and NAICS code. The information source is the County Business Patterns from the Census Bureau. The correlation is very robust for different classification of the clusters. ${ }^{10} \mathrm{It}$ is important to mention that the results only apply to teenage workers (low-skilled workers), which are also those for whom a binding minimum wage is more relevant. Therefore, I estimate the effects to prime-age workers (22-54 years old). This estimation serves as a falsification test. The minimum wage effects and its interactions with monopsony are not significantly different from zero. See Table A5.
} 
comparable with the existing literature. Finally, I also report the total effect of the minimum wage for different values of the HHI.

Second, I estimate the effects depending on how much the minimum wage bites the average wage. To measure the bindingness, I calculate the share of the minimum wage relative to the average wage for each county-quarter $\left(\frac{M W}{A v g \text { Wage }}\right)$. The objective is to measure the interaction of the minimum wage and the two monopsony proxies at different levels of the minimum wage. The more the minimum wage bites the equilibrium wage in a county, the more negative must be the effects on employment compared to in counties where the minimum wage is well below the average wage.

\subsection{Baseline Specifications}

The first specification is the interaction of the minimum wage and the two variables of monopsony. The coefficient of the interaction measures how the impacts of minimum wage depend on the degree of labor market monopsony.

$$
\mathrm{y}_{\mathrm{it}}=\alpha+\beta_{1} \operatorname{Ln}(\mathrm{MW})_{\mathrm{it}}+\beta_{2} \mathrm{M}_{\mathrm{it}}+\beta_{3} \mathrm{M}_{\mathrm{it}} * \operatorname{Ln}(\mathrm{MW})_{\mathrm{it}}+\gamma \mathrm{X}_{\mathrm{it}}+\phi_{i}+\tau_{\mathrm{t}}+\varepsilon_{\mathrm{it}}
$$

$\mathrm{y}_{\mathrm{it}}$ is the variable of interest (log of the teenage employment $\left.{ }^{11}\right)$ in county $i$ in the period $t . \mathrm{MW}_{\mathrm{it}}$ is the minimum wage, and $\mathrm{M}_{\mathrm{it}}$ is the monopsony variable (HHI or labor-mobility). $\beta_{1}$ measures the effect of the minimum wage under perfect $\operatorname{competition}^{12}(\mathrm{M}=0)$, and $\beta_{3}$ is the estimation of the difference between the effect of the minimum wage in monopsonistic labor markets $(\mathrm{M}=$ 1) and the effect on a competitive market $(M=0)$. Technically, $\beta_{3}$ measures such a difference, so the difference depends on the level of concentration. $\beta_{2}$ is the effect of monopsony on

\footnotetext{
11 I am using employment because the QWI measures employment instead of employment rate as the CPS. However, this is controlled with the log of teen population variable.

12 Note that $\mathrm{HHI}=0$ and low mobility $=0$; both measure perfect competition. If the low mobility variable is equal to zero, it means that all the workers move to different industries every time they change jobs.
} 
employment. $\mathrm{X}_{\mathrm{it}}$ is a vector of covariates: $\log$ of the total population, log of the teenage population, and total employment in the private sector. Finally, the fixed effects by geographic area $\left(\phi_{i}\right)$ and time $\left(\tau_{\mathrm{t}}\right)$ are included in the equation. ${ }^{13}$

The following specification adds interaction of the minimum wage and industry for the HHI variable. In this case, the data are not aggregated, and the unit of observation is industry (cluster), county, and time. It is possible that the HHI partly reflects product market power, and the interaction effect of the minimum wage with HHI might not reflect only monopsony power. ${ }^{14}$ Hence, there is a potential omitted variable (product market power $\times$ minimum wages) that correlates with $\mathrm{HHI}$ and minimum wage interaction. Thus, the interaction of minimum wages and industry is necessary to minimize this potential bias.

$$
\begin{gathered}
\mathrm{y}_{\mathrm{jit}}=\alpha+\beta_{1} \operatorname{Ln}(\mathrm{MW})_{\mathrm{jit}}+\beta_{2} \mathrm{HHI}_{\mathrm{jit}}+\beta_{4} \mathrm{HHI}_{\mathrm{jit}} * \operatorname{Ln}(\mathrm{MW})_{\mathrm{jit}}+\beta_{5} \text { Industr }_{\mathrm{jit}} * \\
\operatorname{Ln}(\mathrm{MW})_{\mathrm{jit}}++\gamma \mathrm{X}_{\mathrm{it}}+\phi_{i}+\tau_{\mathrm{t}}+\psi_{j}+\varepsilon_{\mathrm{jit}}
\end{gathered}
$$

$j$ is the industry or cluster, and Industr $y_{\mathrm{jit}}$ is a dummy variable to separate the minimum wage effect by industry. $\beta_{5}$ measures the minimum wage effect by industry with respect to the dropped industry $\left(\beta_{1}\right)$ under perfect competition. $\beta_{4}$ is the average effect of the minimum wage under monopsony with respect to all the industries. Finally, the $\psi_{j}$ term is included in the equation to control for industry fixed effects.

\subsection{Minimum Wages and Different Degrees of Concentration}

My second identification aims to estimate the effect of the minimum wage under full monopsony (either HHI=1 or low-mobility=1) with different degrees of minimum wage bindingness. The

\footnotetext{
${ }_{13}$ All the regressions are weighted for the total population of the county.

${ }^{14}$ Note that the response of employment to a higher minimum wage might vary by industry (depending on a set of variables that, according to Marshall's Laws, affect the elasticity of labor demand).
} 
objective is to identify the effect of the minimum wage depending on the wage of equilibrium. For example, an increase in the minimum wage could have positive effects on employment if the wage is below the wage of perfect competition (the supply curve constrains the impact), and it could have adverse effects if the wage is higher than the perfect competition level (the demand curve constrains the wage). As I explained, the bindingness is measure as the minimum wage relative to the average wage in each county-quarter. I estimate the effects as follows:

$$
\mathrm{y}_{\mathrm{dit}}=\alpha+\beta_{1} \operatorname{Ln}(\mathrm{MW})_{\mathrm{dit}}+\beta_{2} \mathrm{M}_{\mathrm{it}}+\beta_{3} \operatorname{Ln}(\mathrm{HHI})_{\mathrm{it}} * \operatorname{Ln}(\mathrm{MW})_{\mathrm{dit}}+\gamma \mathrm{X}_{\mathrm{it}}+\phi_{i}+\tau_{\mathrm{t}}+\varepsilon_{\mathrm{it}}
$$

Equation (4.3) describes the specification for interactions where $d$ is the number of deciles of the minimum wage bindingness $\left(\frac{M W}{\operatorname{Avg} \text { Wage }}\right)$. I estimate equations for $\mathrm{d}=1,2, \ldots, 10$ separately and evaluate all the variables in the mean with $\mathrm{M}_{\mathrm{it}}=1$, and I calculate the marginal effect of the

$\operatorname{Ln}(\mathrm{MW})_{\text {dit }}$ on $\mathrm{y}_{\text {dit }}$. The results are reported for all the coefficients in Figure 5. Theoretically, if the minimum wage is very low, there must be no effects on teenage employment, because it is not relevant (very few workers earn less than the minimum wage). However, under full monopsony, results must be positive for a certain level of bindingness, and the effect must be less positive (and even negative) if the minimum wage is too high.

\subsection{Controlling for Possible Multicollinearity and External Shocks}

Two potential problems arise in my specification. First, it is possible that multicollinearity maybe introduced if minimum wage changes affect HHI. I verify if they are correlated by estimating the relation between the $\mathrm{HHI}$ and the minimum wage. There is not a significant correlation between minimum wages and HHI (see Appendix A). Second, the HHI effect can be confounded with an external shock. For instance, if a shock reduces the number of firms in a country, the employment will decrease and the HHI will increase, creating the false interpretation 
that the HHI is affecting the employment. To reduce this possible bias, I propose two specifications.

First, I estimate equation (4.1) which use the period average of the HHI instead of the variation over time (equation 4.4), and second, I estimate the average HHI using the first two years (2000 and 2001) (equation 4.5), and I then use this average to calculate the effects over the period 2002-2016. These approaches reduce not only the possible bias of external shocks but also the possible effects of the minimum wage on HHI.

$$
y_{i t}=\alpha+\beta_{1} \operatorname{Ln}(M W)_{i t}+\beta_{2} \overline{H H I}_{i}+\beta_{3} \overline{H H I}_{i} * \operatorname{Ln}(M W)_{i t}+\gamma X_{i t}+\phi_{i}+\tau_{t}+\varepsilon_{i t}
$$

$$
y_{i t}=\alpha+\beta_{1} \operatorname{Ln}(M W)_{i t}+\beta_{2} \overline{\mathrm{HHI}}_{00-01, \mathrm{i}}+\beta_{3} \overline{\mathrm{HHI}}_{00-01, \mathrm{i}} * \operatorname{Ln}(\mathrm{MW})_{\mathrm{it}}+\gamma \mathrm{X}_{\mathrm{it}}+\phi_{i}+\tau_{\mathrm{t}}+\varepsilon_{\mathrm{it}}
$$

$\overline{\mathrm{HHI}}_{\mathrm{i}}$ is the average of the $\mathrm{HHI}$ in the period $2000-2006$ by county, and $\overline{\mathrm{HHI}}_{00-01, \mathrm{i}}$ is the average only for the year 2000-2001 by county. Note that both variables vary between counties but do not variable in time.

Note that another approach would be to use simple lags instead of the average of a previous period. However, simple lags may be less effective depending on the shock. If the effects of the shock are persistent and last more than a quarter, simple lags will not be enough to reduce the bias.

\section{Results}

In this section, I first present the effect of the concentration index and labor mobility on teenage wages to verify that the measurement is consistent with the theory and the previous literature. Second, I show the impact of the interactions of the minimum wage and the monopsony variables on teenage workers. Third, I present a specification that estimates the effects of 
minimum wages under a monopsony labor market for different levels of minimum wage. The objective of the last item is to verify if minimum wages have different effects depending on the equilibrium wage (supply- or demand-constrained). Lastly, I estimate the interactions using alternative measures of HHI to account for possible bias.

\subsection{Effects of Labor Market Concentration on Teenage Workers' Wages}

In Table 2, I estimate the effect of the HHI on wages. In all the tables, I present in column (1) the effects using the HHI and in column (2) using the labor mobility.

Both monopsony variables have negative effects on the average wages of teenage workers among all the columns. However, it is only significant for the HHI. An increase of one standard deviation in the HHI implies a change in the elasticity of -0.099 . These numbers are similar to those found in the papers by Benmelech et al. (2018) and Lipsius (2018) ${ }^{15}$ although, they are calculating the HHI at the firm level. These results also confirm that the measurement of the industrial HHI is highly correlated with the firm HHI. The result also aligns with the monopsony theory. When firms have more monopsonistic power, the equilibrium wage should be lower than in perfect competition.

\subsection{Impacts of Minimum Wages in Concentrated Labor Markets}

In this section, I estimate the impact of minimum wages interacted with the monopsony variables. The effects on teenage employment are presented in Table 3. The specifications of each column are the same as in Table 2. The first row measures the effect of the monopsony variable in employment. Both the HHI and labor mobility are negative and significant. These

\footnotetext{
${ }^{15}$ Benmelech et al. (2018) estimate an elasticity of the HHI on wages of -0.017 ; however, they estimate effects for all firms. In the case of Lipsius (2018), the effect is much higher (a -0.07 elasticity to wages).
} 
results are also consistent with theory, as they predict that the higher the monopsony power, the lower the employment level. The interaction (in the second row) measures the differentiated effect of minimum wages when $\mathrm{HHI}=1$ or low mobility=1, that is, the difference between full monopsony and competitive markets. The elasticity is positive and significant across both columns. This result is also consistent with theory, as firms hiring teenage workers are more likely to be constrained by the minimum wage. It can be inferred that most of the firms are supply-constrained because interaction elasticity is positive.

In the next rows I present the effect of the minimum wage on employment for different levels of monopsony. $\mathrm{HHI}=0$ or low mobility $=0$ is equivalent to the effects of the minimum wage on the employment under perfect competition. For the HHI, the elasticity is -0.418 and significant. The elasticity is higher than the usual elasticity estimates in the literature because the effects are estimated in the more competitive labor markets of the U.S. In contrast, if the $\mathrm{HHI}=1$, the effect is positive (insignificant). The higher the HHI, the less negative is the effect of the minimum wage on teenage employment. It is also important to note that the effect becomes insignificant around an HHI of 0.5. The mean HHI for all the U.S. is 0.595. Thus, monopsony may be explaining recent insignificant effects on teenage employment. For the case of the lower mobility, the same pattern arises: the lowest the mobility, the effects of the minimum wage on employment are less negative. However, it is important to note that the effect is never significantly different from zero.

To compare the HHI elasticities with Azar et al. (2019), an increase of one standard deviation in the $\mathrm{HHI}$ is associated with an increase in the employment elasticity of the minimum wage of 0.05, whereas in Azar et al. (2019) the increase to the employment elasticity is around 0.2. Thus, the results are similar; however, it is important to point out that the sample is very 
different. I measure the effect across all the U.S. and all industries; in contrast, Azar et al. (2019) are only estimating for a few occupations.

The results imply that, under monopsonistic labor markets, raising the minimum wage can be a good policy to increase the income of those workers that are at the bottom of the income distribution without dealing with a high opportunity cost. However, it is also crucial to understand that, in areas where the labor market is more competitive, an increase in the minimum wage can hurt employment.

To better understand the effects on employment, using the coefficients of Table 3, I calculate in Table 4 the share of the teenage population that should have negative and positive effects depending on the level of HHI. Minimum wages have negative and significant effects on most of the teenage employment $(55.81 \%)$ in the U.S. and the positive effects (insignificant) in only $0.12 \%$ of the employment. However, this also means that the effect of the minimum wage is not significantly different from zero for $44.19 \%$ of teenage employment.

\subsection{Impacts of Minimum Wages on Employment in Monopsonistic Labor Markets: Different Levels of Minimum Wage}

In a monopsony model, the minimum wage effect depends on the equilibrium wage and not only on the degree of monopsony. The prediction of the monopsony model is ambiguous, even if the labor market has monopsonistic characteristics. For example, an increase in the minimum wage could have positive effects on employment if the wage is below the wage of perfect competition (the supply curve constrains the impact), and it could have adverse effects if the wage is higher than the perfect competition level (the demand curve constrains the wage). In order to examine this possibility, I estimate the minimum wage effects for different levels of the minimum wage bindingness. To make it more comparable among counties and to better measure 
the bindingness, I compute the average wage in the county divided by its minimum wage (i.e., degrees of bindingness) and run regressions by deciles of the bindingness. ${ }^{16}$

Instead of presenting all the estimations, I plot the marginal effect of the minimum wage, either $\mathrm{HHI}=1$ or low-mobility=1, which means that we are comparing the effect of the minimum wage in full monopsony labor markets but at a different degree of the minimum wage bindingness. ${ }^{17}$

As shown in Figure 4, the HHI and labor mobility have a similar pattern. At very low levels of bindingness (i.e., the minimum wage is almost irrelevant), the elasticity is positive but very small and insignificant. The elasticity is close to zero because, at low levels, an increase in the minimum wage has almost a null effect on employment. In contrast, at the second decile of bindingness, the minimum wage has a more substantial positive and a significant effect on teenage employment. As elasticity gets smaller, the minimum wage bites the average wage to a greater extent, which means that the minimum wage is getting closer to the equilibrium wage. In both monopsony variables, the elasticity became negative in the $10^{\text {th }}$ decile, but it is insignificant.

\subsection{Robustness Tests}

In this section, I test for different issues that affect the main results. First, I test if the results hold if I use different classification to form the clusters for the HHI. Second, I test for a potential omitted variable. The effects of the minimum wage and monopsony on teenage employment are robust to different minimum wages' elasticities depending on the industry and its market power. Third, I test for possible external shocks that affect both the employment and the HHI.

\footnotetext{
${ }^{16}$ In the Appendix, Figure A2, I also present the results for quintiles. The interpretation of the result is the same for deciles and quintiles.

${ }^{17}$ I estimate the same figures for different levels of the HHI and low mobility, and for all the HHI cluster classifications. Results are very similar at higher levels of monopsony. Results available upon request.
} 


\section{Testing Different Cluster Classifications}

In Table 5, I estimate elasticities of the minimum wage interacted with the HHI as in Table 3, but instead, I used different classification methods for the clusters. Column (1) defines the labor market as a 3-digit code of NAICS and counties; the assumption is that workers cannot move (or at least that it is difficult to do so) to other industries and counties, and the NAICS code defines their labor market. Column (2) defines the labor market as the flexible classification, which allows all the links, creating only two big clusters. Column (3) defines the labor market with the "top pairs" classification that only allows to form clusters of the two more connected industries.

The elasticities are very consistent with those in Table 3. The HHI coefficient is negative and significant, and the interaction is positive and significant. For all the cases, if the $\mathrm{HHI}=0$, the minimum wage effect on the employment is negative and higher than the average in the literature. Also, if the $\mathrm{HHI}=1$, the effect on employment is positive and insignificant.

\section{Testing for Possible Omitted V ariable}

My analysis is centered on heterogenous minimum wage effects at the county level of concentration, but one concern is that the effects are different depending on the industry. It is possible that the HHI partly reflects product market power, and the interaction effect of the minimum wage with the HHI might not reflect only monopsony. There is a potential omitted variable (product market power interacted with minimum wages) that correlates with the interaction of $\mathrm{HHI}$ and the minimum wage. Thus, including the interaction of industry with minimum wage accounts for this. 
In Table 6, I estimate the effects with an interaction of the minimum wage and industries to allow for different effects by industry, with three-way fixed effects (time, county, and industry). I present the specification using HHI and labor mobility first, but I also add the other

three different measures of $\mathrm{HHI}$ to see if the results are consistent. In addition, instead of reporting all the coefficients for each industry interaction, I report only the minimum wage average effect (i.e., evaluating at the average value of all the variables including the dummies and with $\mathrm{HHI}=0)$.

The interaction of the monopsony variable and minimum wages is still positive and significant for all the measures of $\mathrm{HHI}$ and for the labor mobility, which indicates that the results are very robust, even when controlling by the possible bias of the markup and using three-way fixed effects. The first row shows the average effect of the minimum wage under perfect competition (all the industrial dummies are evaluated in the mean, and the control variables as well). The minimum wage is negative and insignificant. It is not significant, perhaps because the data are at the industry level, and the effects vary considerably among industries.

\section{Possible Multicollinearity and External Shocks}

Two possible concerns about the estimations are that the HHI or the mobility are correlated with the minimum wage. One is that the minimum wage may be correlated with the HHI or the labor mobility (because it can affect the employment level and the flows). The data suggest it is not the case because there is no significant relationship between HHI-mobility and the minimum wage (See Table A1 in the Appendix).

Another concern more specific to the HHI is that it can be affected by an external shock. For instance, suppose some firms are closed in an area due to a shock. Then, HHI will rise, and employment will be lower; thus, it is not possible to attribute the effect to the HHI. To deal with 
this problem, I follow two approaches. First, I estimate the coefficients of Table 3, but instead, I use the period average of the HHI. Second, I estimate the average $\mathrm{HHI}^{18}$ for the first two years (2000 and 2001), and I then use this average to calculate the estimates over the period 20022016. These approaches reduce not only the possible bias of external shocks, but also the possible effects of the minimum wage on $\mathrm{HHI}$.

In Table 7, I present the results for both approaches. Panel A uses the average of the monopsony variables during 2000-2016, and Panel B during 2000-2001, while the regressions are for the period 2002-2016. Note that the HHI variable is not included because it does not vary in time, so it is collinear with the fixed effects. In both specifications, the results are very similar to the ones in Table 3. Hence, in general, we can disregard the external shocks as explaining the effect of the HHI on employment. The main conclusions are still valid, and the monopsony proxies explain the heterogeneous effects of the minimum wage on employment.

\section{Conclusions}

The effects of minimum wages have been controversial, and there are a considerable number of papers that find no negative effects on employment. These papers propose monopsony as one plausible explanation. This paper contributes to the minimum wage literature by focusing on estimating minimum wages effects when the labor markets are far from competitive.

I identify these effects by estimating the impact of the policy on the employment of teenage workers, which is a group that is more likely to be affected.

The main finding of the paper is that minimum wages have mixed effects on employment depending on the degree of monopsony of the labor markets and its equilibrium wage. As theory

\footnotetext{
${ }^{18}$ For robustness, I also added a column for labor mobility. However, it is hard to think of a scenario wherein a shock affects the labor mobility and the employment at the same time.
} 
predicts, minimum wages have negative effects on competitive areas, but they have positive effects on the more monopsonistic areas (where firms have the power to set the wage). However, the range where minimum wages have positive effects is relatively small.

Another contribution is the estimation of the effect on monopsonistic labor markets for different levels of the minimum wage. As predicted in the monopsony model, when firms are unconstrained because the minimum wage is not binding, there are insignificant effects. In contrast, increases in minimum wages have positive effects on employment at higher levels of monopsony in firms that are supply-constrained Also, at a very high level of bindingness, the minimum wage has negative and insignificant effects on employment, even if there is high concentration or low labor mobility.

There are some areas of potential improvement for this paper. For instance, using data at the firm level could enhance the precision of the estimates because the measurement of concentration would be more accurate. Additionally, having firm-level data would allow the estimation of the supply elasticity to the firm, which is a more direct measure of monopsony. These two issues do not bias the results significantly. The effects of the HHI on wages in this paper are consistent with the literature that uses HHIs calculated directly from firms.

Moreover, the industry clusters for labor markets relax the assumption that workers can only work in one sector and allow workers to move to other industries. In other words, the labor market is determined by a cluster of industries that demand similar skills from workers instead of assuming that an occupation or an industry determines the labor supply. The HHI and labor mobility are close measurements of monopsony; therefore, results are still valid.

This paper's results suggest that minimum wages can be tied closely to local labor market conditions. Usually, minimum wages are set in large areas without taking into consideration the local labor market. In the U.S., minimum wages are set by the state and federal level, but in many 
countries, the policy is implemented nationwide. This is important because a minimum wage policy can improve and correct market problems like monopsonies, but it is also important to be aware that it can hurt workers in more competitive areas. 


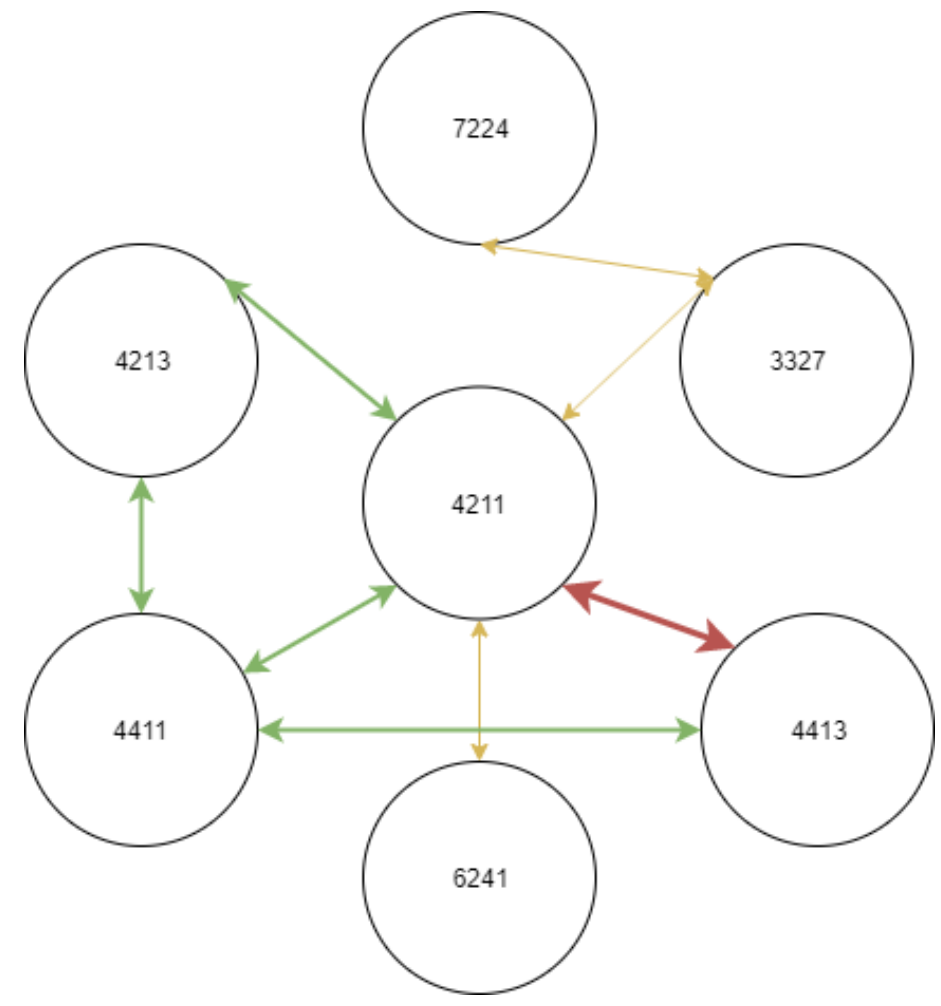

Figure 1. Creation of Clusters of Industries or Labor Markets

Notes: The red link indicates that the two industries have more relative flows than any other pair (top pair). Green links indicate a strong relationship (the top 3 pairs or more than $90^{\text {th }}$ of relative flows between industries); the sum of red and green links defines the preferred classification. Yellow links are week connections; the sum of yellow, green, and red links define the flexible method. 


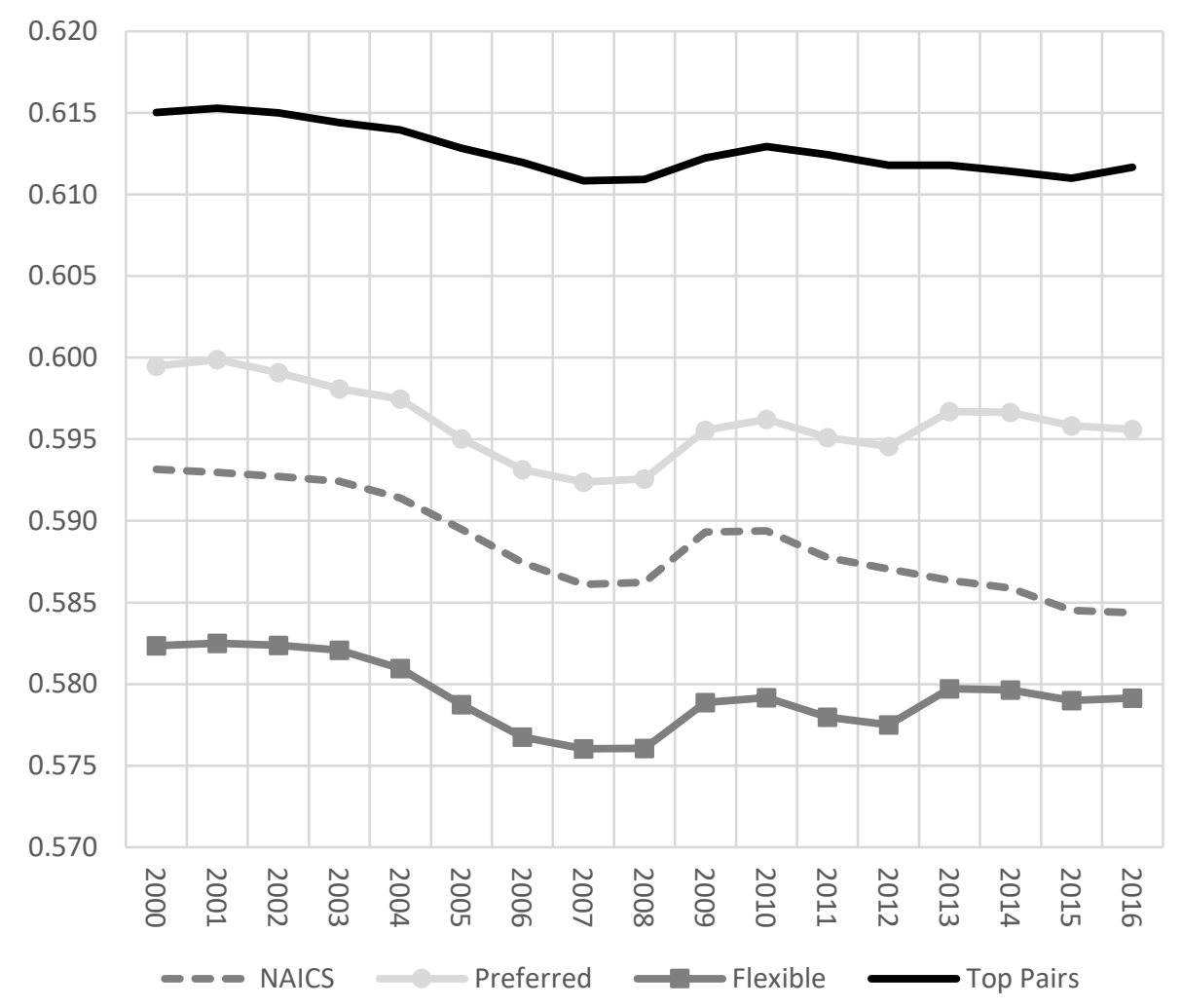

Figure 2. Evolution of the HHI in the U.S.: 2000-2016

Note: The HHI is estimated by averaging industries and counties by year (weighted by population).

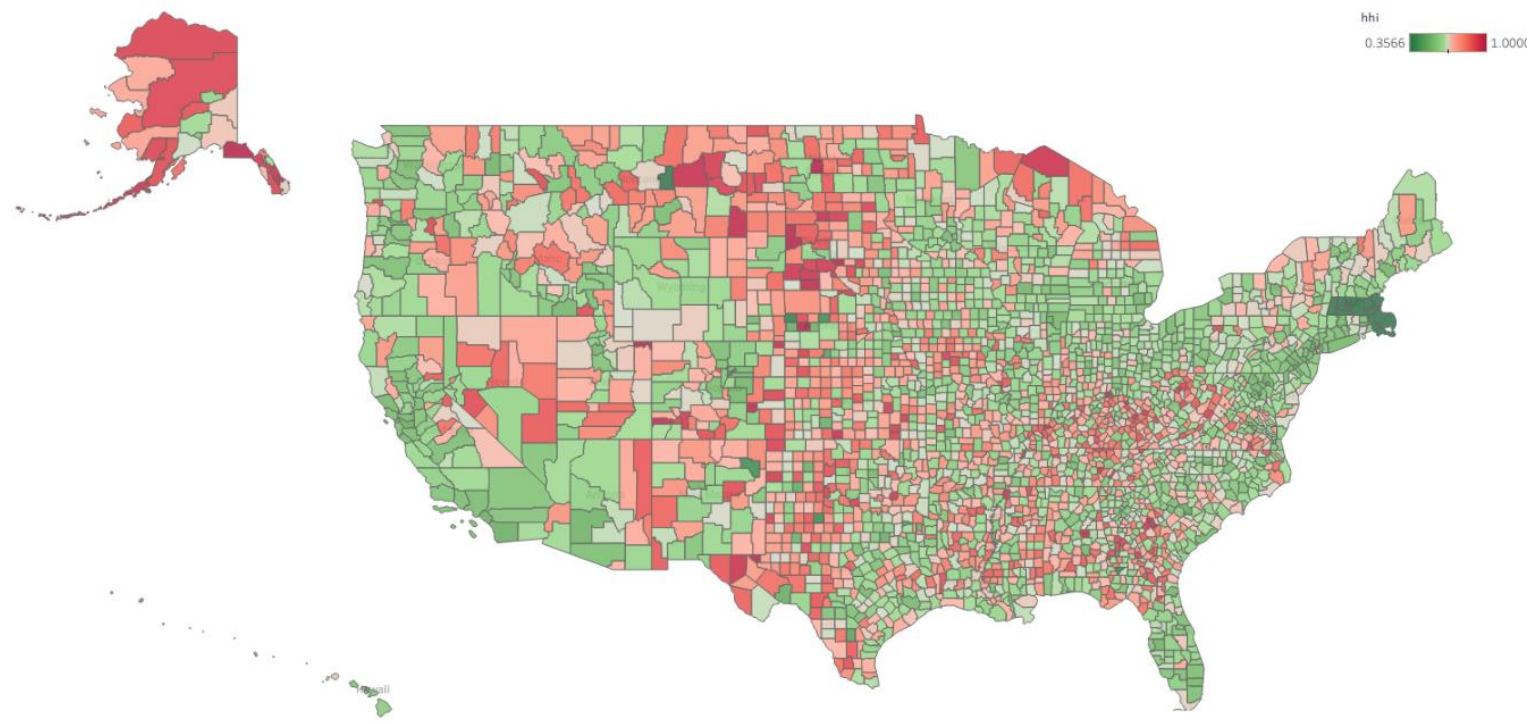

Figure 3. HHI in the U.S. across Counties: 2000-2016

Note: The HHI is estimated by averaging industries and year by county (weighted by population). I use the hybrid method for the estimation of the HHI. 
(1) HHI

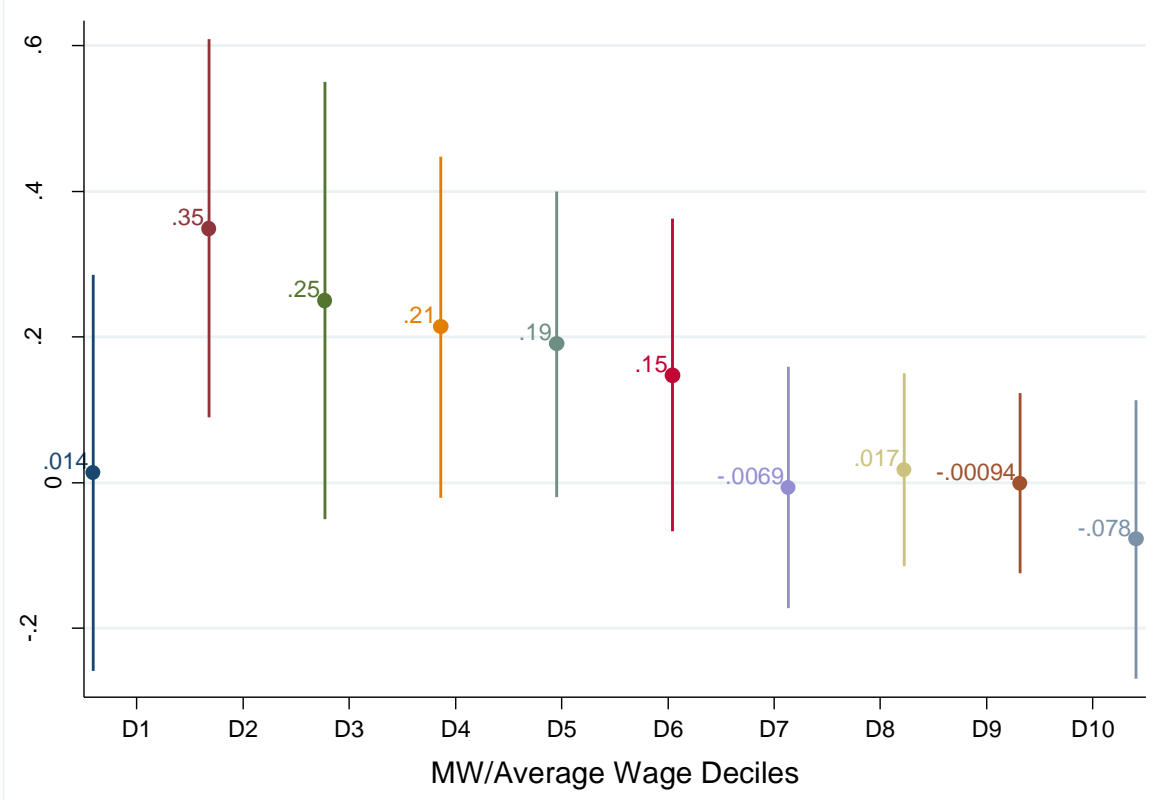

(2) Low Mobility

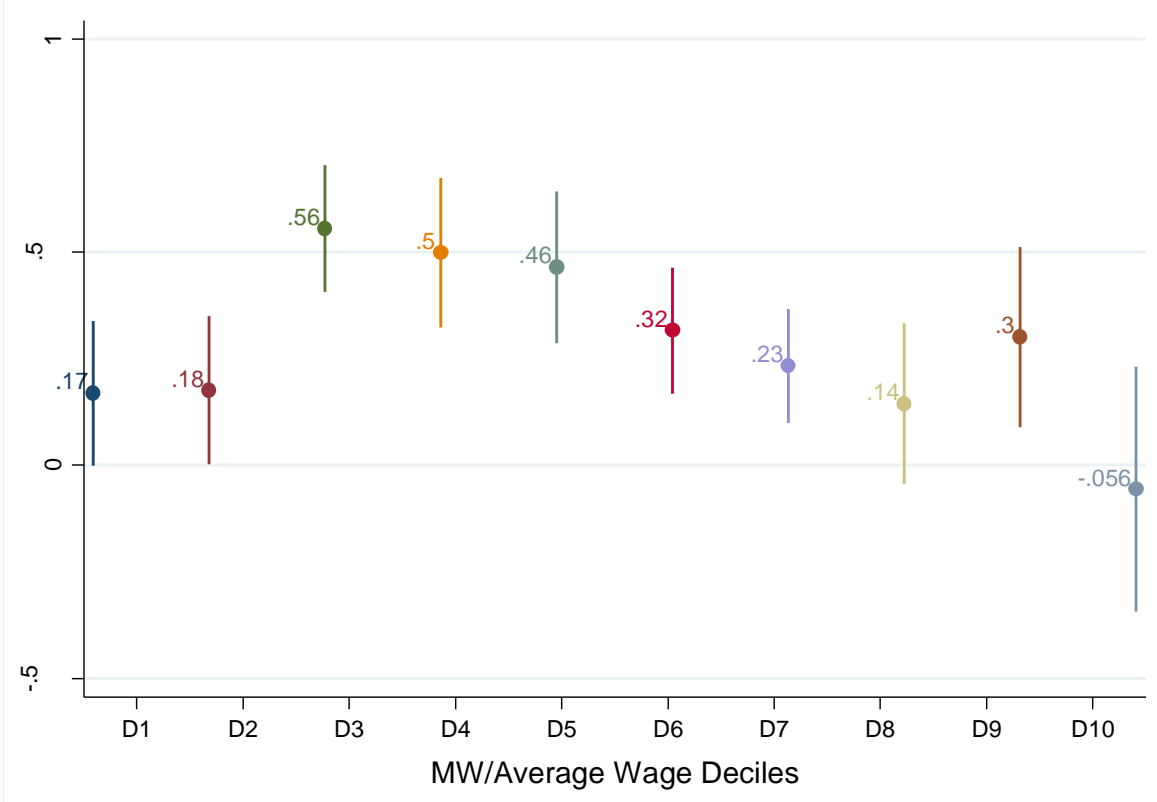

Figure 4. Effect of the Minimum Wage under Monopsony by Deciles

Note: I calculate MW/Average Wage and split the estimation in deciles. The higher the decile, the more binding is the minimum wage. All the estimations are evaluated with $\mathrm{HHI}$ or mobility equal to one. HHI=1 indicates full concentration. Mobility $=1$ implies that the worker remains in the same industry for all the periods. 
Table 1. Average Number of Establishments by HHI

\begin{tabular}{|l|r|r|r|r|}
\hline & \multicolumn{2}{|c|}{ HII } & \multicolumn{2}{c|}{ Low Mobility } \\
\hline & \multicolumn{1}{|c|}{ Mean } & Median & Mean & Median \\
\hline Monopsony=1 & 5.38 & 3.18 & 581.35 & 361.81 \\
\hline $90^{\text {th }}$ & 10.96 & 7.75 & 847.61 & 564.40 \\
\hline $10^{\text {th }}$ & $1,815.18$ & 611.20 & $2,135.22$ & 826.06 \\
\hline $5^{\text {th }}$ & $2,261.91$ & 708.59 & $1,689.81$ & 708.81 \\
\hline
\end{tabular}

Note: I calculate the average and the median number of establishments if the HHI=1 and Mobility=1, as well as for the $90^{\text {th }}, 10^{\text {th }}$, and $5^{\text {th }}$ percentiles of both variables across observations (county-time).

Table 2. Effects of the HHI and Low Mobility on the Log of Teenage Wages

\begin{tabular}{lcc}
\hline & $(1)$ & $(2)$ \\
Dependent Variable: Ln (Wage) & HHI & Low Mobility \\
\hline \multirow{3}{*}{ HHI } & $-0.0993^{* * *}$ & \\
& $(0.0254)$ & \\
Low Mobility & & -0.127 \\
& & $(0.161)$ \\
Constant & $8.128^{* * *}$ & $6.784^{* * *}$ \\
& $(0.716)$ & $(1.391)$ \\
& & \\
Observations & 199,168 & 18,121 \\
R-squared & 0.718 & 0.888 \\
\hline
\end{tabular}

Robust clustered standard errors in parentheses by states.

*** $\mathrm{p}<0.01, * * \mathrm{p}<0.05, * \mathrm{p}<0.1$

Notes: All specifications include two-way fixed effects (county and time). Control variables are the log of the total population, the $\log$ of teenage employment, and $\log$ of total private-sector employment. HHI measures concentration: $\mathrm{HHI}=0$ implies perfect competition, and $\mathrm{HHI}=1$ means full concentration. Column (1) defines the labor market as clusters of industries, which consists of keeping only connections or links between industries with more relative flows of workers (top three links with highest flows with more than $90^{\text {th }}$ percentile of relative flows between industries). Column (2) uses low mobility, which measures the percentage of workers who, when they change jobs, do not change industries. See Section 4 for more details. 
Table 3. Effects of the Log of the MW Interacted with the HHI and Low Mobility on the Log of Teenage Employment

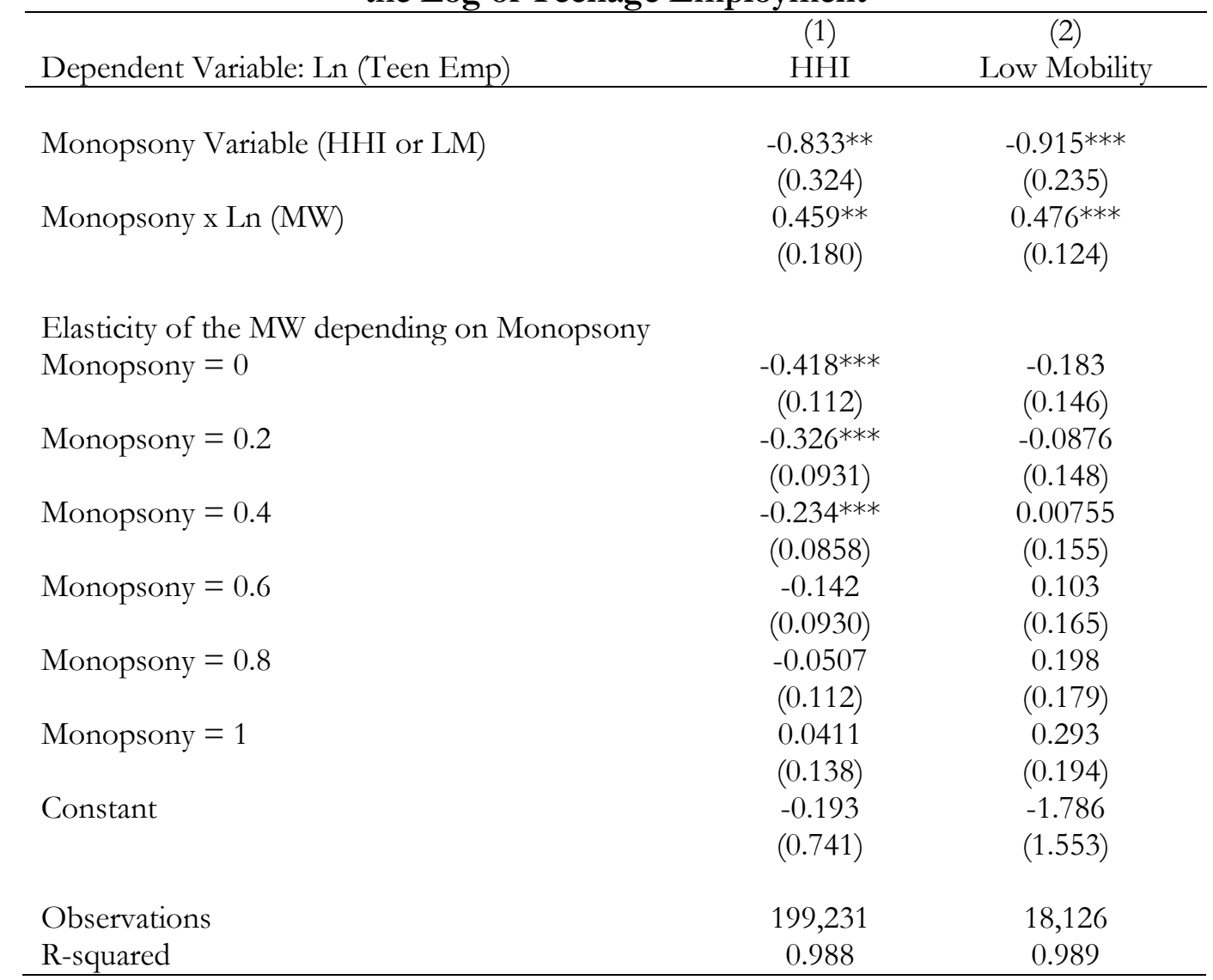

Robust clustered standard errors in parentheses by states.

*** $\mathrm{p}<0.01,{ }^{* *} \mathrm{p}<0.05,{ }^{*} \mathrm{p}<0.1$

Notes: All specifications include two-way fixed effects (county and time). Control variables are log of the total population, the $\log$ of teenage employment, and $\log$ of total private-sector employment. HHI measures concentration: $\mathrm{HHI}=0$ implies perfect competition, and $\mathrm{HHI}=1$ means full concentration. Column (1) defines the labor market as clusters of industries, which consists of keeping only connections or links between industries with more flows of workers (top three links with highest flows with more than $90^{\text {th }}$ percentile of relative flows between industries). Column (2) uses low mobility, which measures the percentage of workers who, when they change jobs, do not change industries. See Section 4 for more details. 
Table 4. Percentage of the Teenage Employment by the Significance of the Minimum Wage Effects Depending on the Monopsony Variable

\begin{tabular}{|l|c|}
\hline & $\begin{array}{c}\text { Share of the total } \\
\text { Teenage Employment }\end{array}$ \\
\hline Negative Significant & $55.81 \%$ \\
\hline Negative & $44.06 \%$ \\
\hline Positive & $0.12 \%$ \\
\hline Positive Significant & $0.00 \%$ \\
\hline
\end{tabular}

Notes: I am using the "Hybrid" classification, but the results are very similar to the other classifications. The calculations are computed as follows: (1) I estimate the coefficients with the regression models, (2) use the coefficients to estimate the MW effects on the teenage employment, (3) determine at what level of HHI the MW effect is negative, negative significant, positive, and positive significant; (4) aggregate the employment by HHI, and (5) calculate the shares of employment where the MW has negative, negative significant, positive, positive significant effects. The estimation is using the coefficient of the regression model of column (1) in Table 4. 


\section{Table 5. Robustness Check: Effects of the Log of the MW Interacted with All the}

Classifications of Clusters for the HHI on the Log of Teenage Employment

\begin{tabular}{lccc}
\hline & $(1)$ & $(2)$ & $(3)$ \\
Dependent Variable: Ln (Teen Emp) & NAICS & Flexible & Top Pairs \\
\hline Monopsony Variable (HHI or LM) & & & \\
& $-0.972^{* * *}$ & $-0.920^{* * *}$ & $-0.998^{* *}$ \\
Monopsony x Ln (MW) & $(0.341)$ & $(0.336)$ & $(0.377)$ \\
& $0.527^{* * *}$ & $0.504^{* *}$ & $0.523^{* *}$ \\
Elasticity of the MW depending on Monopsony & $(0.189)$ & $(0.191)$ & $(0.204)$ \\
Monopsony $=0$ & & & \\
& $-0.458^{* * *}$ & $-0.438^{* * *}$ & $-0.461^{* * *}$ \\
Monopsony $=0.2$ & $(0.133)$ & $(0.125)$ & $(0.145)$ \\
& $-0.353^{* * *}$ & $-0.338^{* * *}$ & $-0.357^{* * *}$ \\
Monopsony $=0.4$ & $(0.109)$ & $(0.102)$ & $(0.117)$ \\
& $-0.247^{* * *}$ & $-0.237^{* * *}$ & $-0.252^{* *}$ \\
Monopsony $=0.6$ & $(0.0958)$ & $(0.0912)$ & $(0.0990)$ \\
& -0.142 & -0.136 & -0.147 \\
Monopsony $=0.8$ & $(0.0961)$ & $(0.0952)$ & $(0.0959)$ \\
& -0.0365 & -0.0354 & -0.0427 \\
Monopsony $=1$ & $(0.110)$ & $(0.113)$ & $(0.109)$ \\
Constant & 0.0690 & 0.0653 & 0.0619 \\
& $(0.134)$ & $(0.139)$ & $(0.134)$ \\
Observations & -0.119 & -0.140 & -0.0320 \\
R-squared & $(0.708)$ & $(0.711)$ & $(0.717)$ \\
& & & \\
& 199,231 & 199,231 & 199,231 \\
& 0.988 & 0.988 & 0.988 \\
\hline
\end{tabular}

Robust clustered standard errors in parentheses by states.

*** $\mathrm{p}<0.01,{ }^{* *} \mathrm{p}<0.05, * \mathrm{p}<0.1$

Notes: All specifications include two-way fixed effects (county and time). Control variables are the log of the total population, log of teenage employment, and log of total private-sector employment. HHI measures concentration: $\mathrm{HHI}=0$ implies perfect competition, and HHI $=1$ means full concentration. Column (1) defines the labor market by 3-digit NAICS code. In column (2), the cluster is defined by all the links; for instance, if industry A is connected to industry $\mathrm{B}$, and industry $\mathrm{B}$ is connected to industry $\mathrm{C}$, then A and C are connected. Column (3) only considers as a cluster the pair of industries with more relative flows between each other. See Appendix B for more details. 
Table 6. Effects of the Log of the MW Interacted with the HHI and Low Mobility on the Log of Teenage Employment, Allowing Different Effects of MW by Industry

\begin{tabular}{|c|c|c|c|c|c|}
\hline $\begin{array}{l}\text { Dependent Variable: Ln (Teen } \\
\text { Emp) }\end{array}$ & $\begin{array}{c}\text { (1) } \\
\text { HHI }\end{array}$ & $\begin{array}{c}\text { (2) } \\
\text { Low } \\
\text { Mobility } \\
\end{array}$ & $\begin{array}{c}(3) \\
\text { NAICS }\end{array}$ & $\begin{array}{c}(4) \\
\text { Flexible }\end{array}$ & $\begin{array}{c}(5) \\
\text { Top } \\
\text { Pairs } \\
\end{array}$ \\
\hline $\operatorname{Ln}(\mathrm{MW})$ & $\begin{array}{l}-0.233 \\
(0.130)\end{array}$ & $\begin{array}{l}0.0907 \\
(0.261)\end{array}$ & $\begin{array}{l}-0.160 \\
(0.129)\end{array}$ & $\begin{array}{l}-0.190 \\
(0.133)\end{array}$ & $\begin{array}{l}-0.142 \\
(0.140)\end{array}$ \\
\hline HHI or Low Mobility & $\begin{array}{c}-0.714^{* * *} \\
(0.120)\end{array}$ & $\begin{array}{l}-0.119^{*} \\
(0.0691)\end{array}$ & $\begin{array}{c}-0.585^{* * *} \\
(0.117)\end{array}$ & $\begin{array}{c}-0.712^{* * *} \\
(0.126)\end{array}$ & $\begin{array}{c}-0.335^{* * *} \\
(0.121)\end{array}$ \\
\hline HHI or Low Mobility x Ln (MW) & $\begin{array}{l}0.389 * * * \\
(0.0615)\end{array}$ & $\begin{array}{l}0.0685^{*} \\
(0.0357)\end{array}$ & $\begin{array}{l}0.314 * * * \\
(0.0602)\end{array}$ & $\begin{array}{l}0.365^{* * *} \\
(0.0625)\end{array}$ & $\begin{array}{l}0.257^{* * *} \\
(0.0654)\end{array}$ \\
\hline Constant & $\begin{array}{c}-0.496 \\
(0.333) \\
2,201,02\end{array}$ & $\begin{array}{c}-7.681 * * \\
(3.136)\end{array}$ & $\begin{array}{c}0.384 \\
(0.371) \\
1,954,25\end{array}$ & $\begin{array}{c}1.147 * * * \\
(0.350) \\
1,921,13\end{array}$ & $\begin{array}{c}-1.400^{* * *} \\
(0.370)\end{array}$ \\
\hline Observations & 1 & 18,001 & 2 & 8 & $2,603,089$ \\
\hline R-squared & 0.818 & 0.970 & 0.831 & 0.831 & 0.793 \\
\hline
\end{tabular}

Robust clustered standard errors in parentheses by states.

$* * * \mathrm{p}<0.01, * * \mathrm{p}<0.05, * \mathrm{p}<0.1$

Notes: All specifications include three-way fixed effects (county, time, and industry). Control variables are the log of the total population, log of teenage employment, and log of total private-sector employment. HHI measures concentration: $\mathrm{HHI}=0$ implies perfect competition, and $\mathrm{HHI}=1$ means full concentration. In addition, all the specifications include interactions of $\mathrm{Ln}(\mathrm{MW})$ by industry. The coefficient reported for $\operatorname{Ln}(\mathrm{MW})$ is the effect evaluated in the average of each industry for $\mathrm{HHI}=0$. Column (1) defines the labor market as clusters of industries, which consists of keeping only connections or links between industries with more relative flows of workers (top three links with highest flows with more than $90^{\text {th }}$ percentile of relative flows between industries). Column (2) uses low mobility, which measures the percentage of workers who, when they change jobs, do not change industries. Column (3) defines the labor market by 3-digit NAICS code. In column (4), the cluster is defined by all the links; for instance, if industry A is connected to industry B, and industry B is connected to industry C, then A and C are connected. Column (5) only considers as a cluster the pair of industries with more relative flows between each other. See Section 4 for more details. 
Table 7. Effects of the Log of the MW Interacted with the HHI and Low Mobility on the Log of Teenage Employment, Average of the HHI in Different Periods

\begin{tabular}{|c|c|c|}
\hline Dependent Variable: Ln (Emp) & $\begin{array}{c}(1) \\
\mathrm{HHI}\end{array}$ & $\begin{array}{c}\text { (2) } \\
\text { Low Mobility }\end{array}$ \\
\hline Ln (MW) & $\begin{array}{c}-0.501 * * * \\
(0.142)\end{array}$ & $\begin{array}{c}-1.123 * * * \\
(0.192)\end{array}$ \\
\hline HHI or Mobility (average) x Ln (MW) & $\begin{array}{c}0.575^{* *} \\
(0.238)\end{array}$ & $\begin{array}{c}1.905^{* * *} \\
(0.376)\end{array}$ \\
\hline Constant & $\begin{array}{l}-0.846 \\
(0.780)\end{array}$ & $\begin{array}{c}-2.918^{* *} \\
(1.098)\end{array}$ \\
\hline $\begin{array}{l}\text { Observations } \\
\text { R-squared }\end{array}$ & $\begin{array}{c}200,052 \\
0.988\end{array}$ & $\begin{array}{c}26,657 \\
0.988\end{array}$ \\
\hline \multicolumn{3}{|l|}{ Panel B: Using the average from 2000-2001 } \\
\hline Dependent Variable: Ln (Emp) & $\begin{array}{c}(1) \\
\mathrm{HHI} \\
\end{array}$ & $\begin{array}{c}(2) \\
\text { Low Mobility }\end{array}$ \\
\hline Ln (MW) & $\begin{array}{c}-0.306^{* *} \\
(0.131)\end{array}$ & $\begin{array}{c}-0.999 * * * \\
(0.294)\end{array}$ \\
\hline HHI or Mobility (average) x Ln (MW) & $\begin{array}{c}0.330 \\
(0.200)\end{array}$ & $\begin{array}{c}1.711^{* * * *} \\
(0.514)\end{array}$ \\
\hline Constant & $\begin{array}{l}-0.967 \\
(0.930)\end{array}$ & $\begin{array}{l}-2.906 \\
(1.896)\end{array}$ \\
\hline $\begin{array}{l}\text { Observations } \\
\text { R-squared }\end{array}$ & $\begin{array}{c}168,219 \\
0.988\end{array}$ & $\begin{array}{c}14,036 \\
0.988\end{array}$ \\
\hline
\end{tabular}

Robust clustered standard errors in parentheses by states.

*** $\mathrm{p}<0.01, * * \mathrm{p}<0.05, * \mathrm{p}<0.1$

Notes: All specifications include two-way fixed effects (county and time). Control variables are the log of the total population, log of teenage employment, and total private-sector employment. $\mathrm{HHI}$ measures concentration: $\mathrm{HHI}=0$ implies perfect competition, and $\mathrm{HHI}=1$ means full concentration. Column (1) defines the labor market as clusters of industries, which consists of keeping only connections or links between industries with more relative flows of workers (top three links with highest flows with more than $90^{\text {th }}$ percentile of relative flows between industries). Column (2) uses low mobility, which measures the percentage of workers who, when they change jobs, do not change industries. See Section 4 for more details. The HHI and mobility do not vary over time; thus, the coefficients are dropped due to collinearity with time. In Panel A uses HHI average of all the period (2000-2016) and in Panel B the average from 2000 to 2001. 


\section{References}

Abel, Will, Silvana Tenreyro, and Gregory Thwaites. (2018). "Monopsony in the U.K." Discussion Papers 1827, Centre for Macroeconomics (CFM).

Allegretto, Sylvia, Arindrajit Dube, and Michael Reich. (2011). "Do Minimum Wage Really Reduce Teen Employment? Accounting for Heterogeneity and Selectivity in State Panel Data." Industrial Relations 15(2).

Allegretto, Sylvia, Arindrajit Dube, Michael Reich, and Ben Zipper. (2013). "Credible Research Designs for Minimum Wage Studies.” IZA Working Paper, 7638.

Azar, José, Emiliano Huet-Vaughn, Ioana Marinescu, Bledi Taska, and Till von Wachter. (2019).

"Minimum Wage Employment Effects and Labor Market Concentration." NBER Working Paper 26101.

Azar, José, Ioana Marinescu, and Marshall I. Steinbaum. (2017). “Labor Market Concentration.” NBER Working Paper 24147.

Benmelech, Efraim, Nittai Bergman, and Hyunseob Kim. (2018). "Strong Employers and Weak Employees: How Does Employer Concentration Affect Wages?” NBER Working Paper 24307.

Bhaskar, V., and To, T. (1999). "Minimum Wages for Ronald McDonald Monopsonies: A Theory of Monopsonistic Competition.” The Economic Journal 109(45), 190-203.

Bhaskar, V., Manning, A., and To, T. (2002). “Oligopsony and Monopsonistic Competition in Labor Markets." Journal of Economic Perspectives 16(2), 155-174.

Card, David, and Alan B. Krueger. (1994). "Minimum Wages and Employment: A Case Study of the Fast-Food Industry in New Jersey and Pennsylvania." American Economic Review 84(4): 772-93.

Card, David, and Alan B. Krueger. (1995). Myth and Measurement: The New Economics of the Minimum Wage. Princeton University Press. Princeton, New Jersey.

Card, David, Ana Rute Cardoso, Joerg Heining, and Patrick Kline. (2018). "Firms and Labor Market Inequality: Evidence and Some Theory." Journal of Labor Economics 36(S1): S13S70.

Dube, Arindrajit. (2019). "Impacts of Minimum Wages: Review of the international evidence." Independent Report. U.K. Government Publication. 
Dube, Arindrajit, T. William Lester, and Michael Reich. (2010). "Minimum Wage Effects Across State Borders: Estimating Using Continuous Counties." The Review of Economics and Statistics 92(4): 945-964.

Dube, Arindrajit, T. William Lester, and Michael Reich. (2016). "Minimum Wage Shocks, Employment Flows, and Labor Market Frictions." Journal of Labor Economics 34(3): 663704.

Dube, Arindrajit, Jeff Jacobs, Suresh Naidu, and Siddharth Suri. (2018). "Monopsony in Online Labor Markets.” NBER Working Paper 24416.

Falch, Torberg. (2010). "The Elasticity of Labor Supply at the Establishment Level”, Journal of Labor Economics, 28(2), 237-266.

Hirsch, Boris, Thorsten Schank, and Claus Schnabel (2010). "Differences in Labor Supply to Monopsonistic Firms and the Gender Pay Gap: An Empirical Analysis Using Linked Employer-Employee Data from Germany”, Journal of Labor Economics, 28(2), 291-330.

Katz, Lawrence F. and Alan B. Krueger. (1992). "The Effect of the Minimum Wage on the Fast Food Industry.” NBER Working Papers 3997.

Lipsius, Ben. (2018). "Labor Market Concentration Does Not Explain the Falling Labor Share." Job Market Paper. University of Michigan.

Manning, Alan. (2003). Monopsony in Motion. Princeton: Princeton University Press.

Molloy, Raven, Christopher L. Smith, and Abigail Wozniak. (2014). "Declining Migration within the U.S.: The Role of the Labor Market.” NBER Working Paper 20065.

Moretti, Enrico. (2011). “Local Labor Markets." in Handbook of Labor Economics, vol. 4B, David Card and Orley Ashenfelter, eds. Amsterdam: Elsevier, 2011, 1237-1313.

Neumark, David. (2019). "The Econometrics and Economics of the Employment Effects of Minimum Wages: Getting from Known Unknowns to Known Knowns." German Economic Review 20(3): 293-329.

Neumark, David, and Willian Wascher. (1994). "Minimum Wage Effects and Low-Wage Labor Markets: A Disequilibrium Approach.” NBER Working Paper 4617.

Rinz, Kevin. (2018). "Labor Market Concentration, Earnings Inequality, and Earnings Mobility." Technical report, U.S. Census Bureau CARRA Working Paper Series.

Robinson, Joan. (1933). The Economics of Imperfect Competition. London: Macmillan. 
Staiger, Douglas O., Joanne Spetz, and Ciarian S. Phibbs (2010) "Is There Monopsony in the Labor Market? Evidence from a Natural Experiment”, Journal of Labor Economics, 28(2), 211-236.

Vaghul, Kavya, and Ben Zipperer. (2016). "Historical State and Sub-State Minimum Wage Data." Working paper. Washington Center for Equitable Growth.

Webber, Douglas A. (2016). "Firm-Level Monopsony and the Gender Pay Gap." Industrial Relations 55(2).

Wessels, Walter John. (1997). "Minimum Wages and Tipped Servers.” Economic Inquiry 43: 334 349. 


\section{Appendix A}

(1) HHI

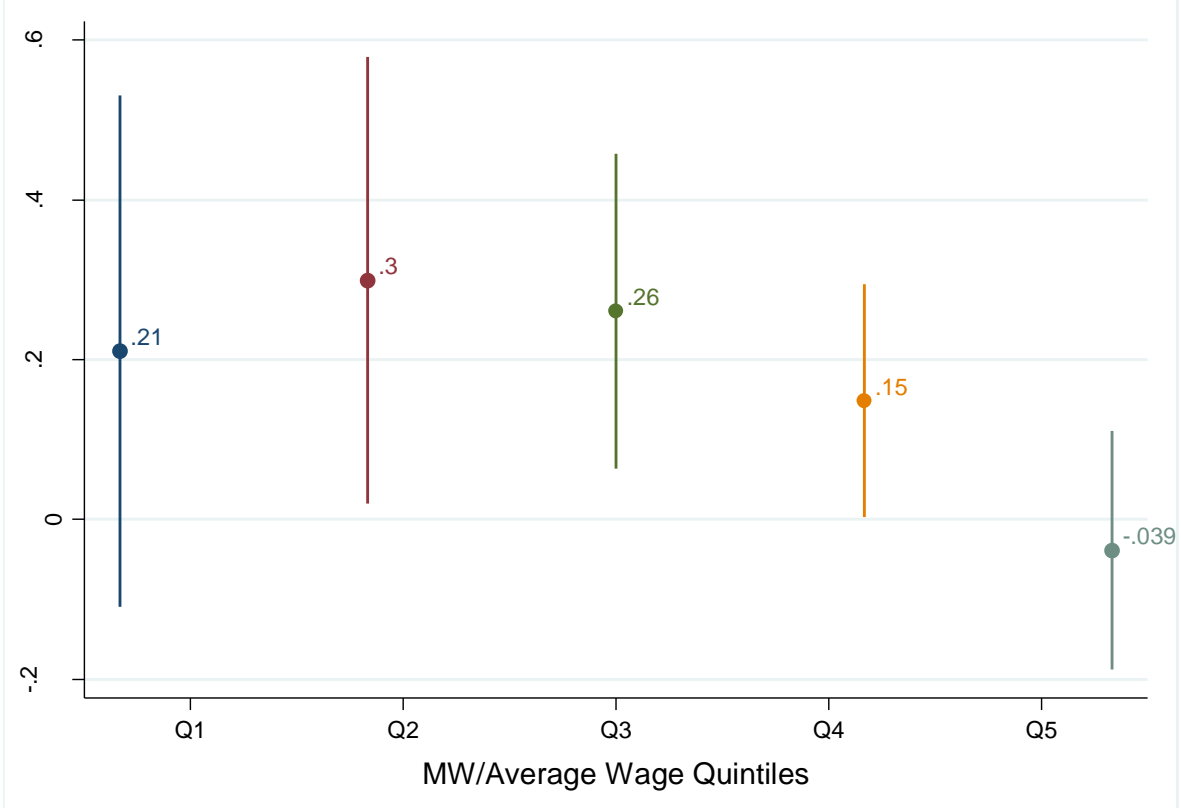

(2) Low Mobility

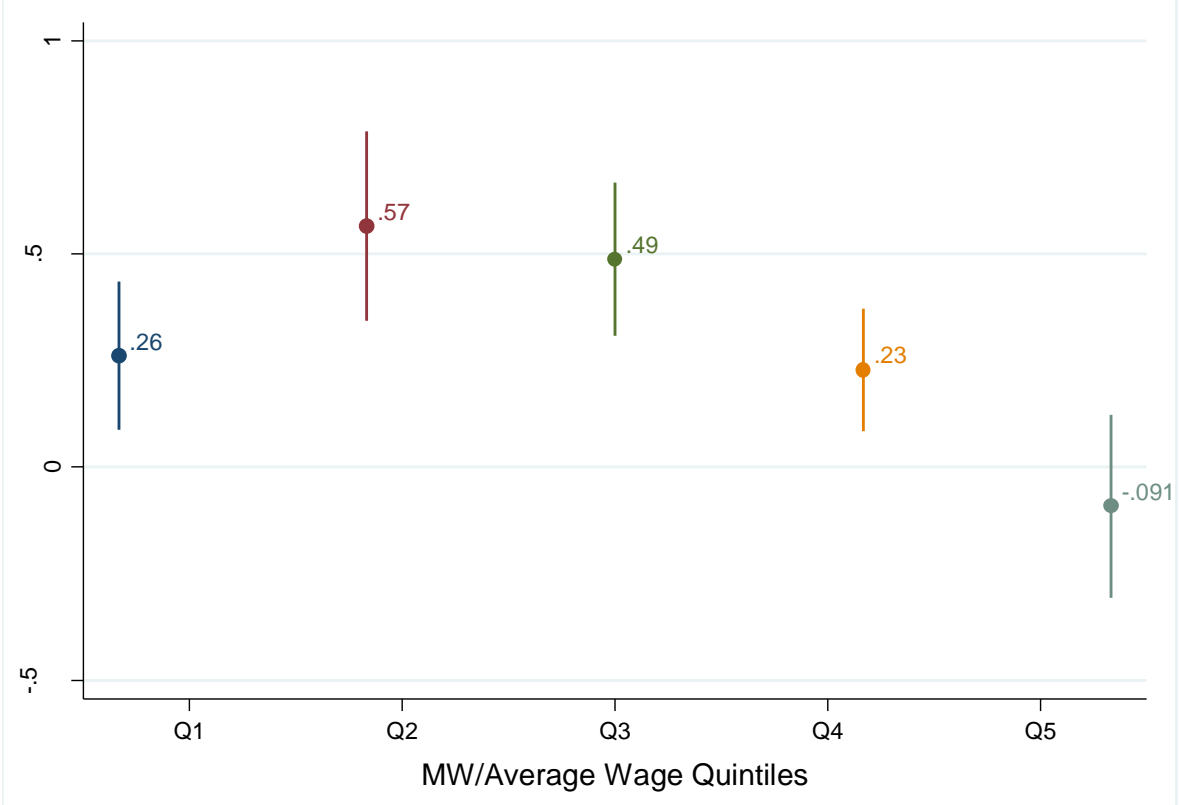

Figure A1. Effect of the Minimum Wage under Monopsony by Quintiles

Note: I calculate MW/Average Wage and split the estimation in quintiles. The higher the quintile, the more binding the minimum wage is. All the estimations are evaluated with $\mathrm{HHI}$ or mobility equal to one. $\mathrm{HHI}=1$ indicates full concentration. Mobility $=1$ implies that the worker remains in the same industry for all the periods. 
Table A1. Statistics of the HHI and Low Mobility by Method of Estimation

\begin{tabular}{|l|c|c|c|c|c|}
\hline & Mean & Median & Min & Max & Sd \\
\hline HHI & 0.595 & 0.575 & 0.077 & 1.000 & 0.070 \\
\hline Low Mobility & 0.608 & 0.608 & 0.000 & 1.000 & 0.071 \\
\hline NAICS & 0.587 & 0.570 & 0.169 & 1.000 & 0.069 \\
\hline Flexible & 0.578 & 0.560 & 0.125 & 1.000 & 0.069 \\
\hline Top Pairs & 0.612 & 0.598 & 0.331 & 1.000 & 0.060 \\
\hline
\end{tabular}

Note: The HHI is estimated by averaging industries, counties, and time (weighted by population). Low mobility is calculated as

$$
\text { Labor Mobility }_{i, a, t}=\frac{\text { remained }_{i, a, t}}{\text { remained }_{i, a, t}+\text { moved }_{i, a, t}}
$$

(see section 3 ) and then by averaging industries, counties, and time (weighted by population).

\section{Table A2. Effects of the Log of the Minimum Wage on HHI and Low Mobility}

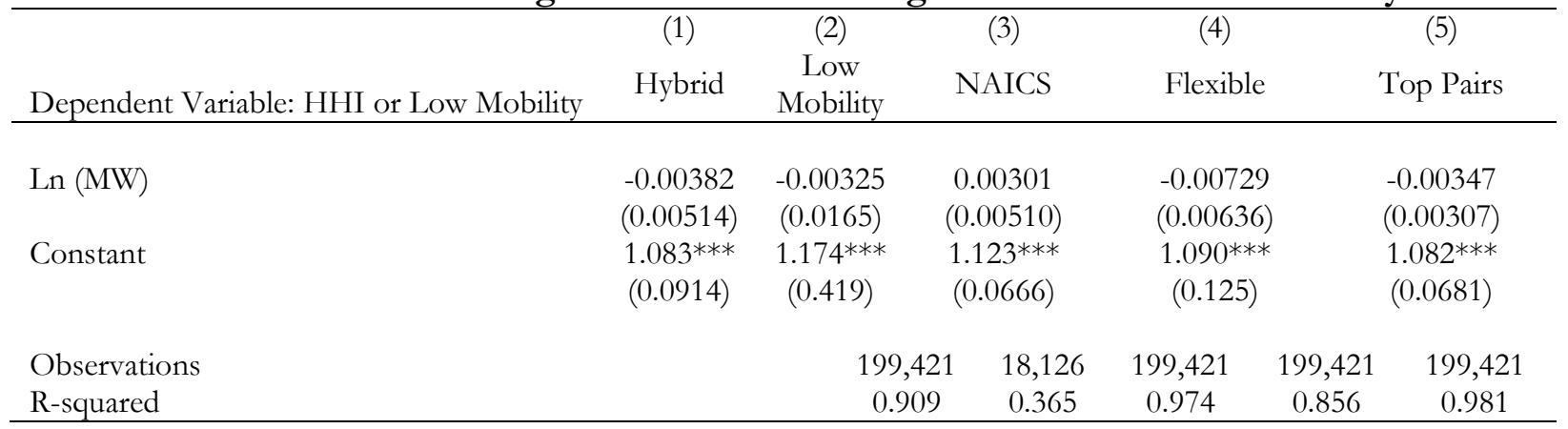

Robust clustered standard errors in parentheses by states.

*** $\mathrm{p}<0.01, * * \mathrm{p}<0.05, * \mathrm{p}<0.1$

Notes: All specifications include two-way fixed effects (county and time). Control variables are the log of the total population, log of teenage employment, and log of total private-sector employment. Column (1) defines the labor market as clusters of industries, which consists of keeping only connections or links between industries with more relative flows of workers (top three links with highest flows with more than $90^{\text {th }}$ percentile of relative flows between industries). Column (2) uses low mobility, which measures the percentage of workers who, when they change jobs, do not change industries. Column (3) defines the labor market by 3-digit NAICS code. In column (4), the cluster is defined by all the links; for instance, if industry A is connected to industry B, and industry B is connected to industry $\mathrm{C}$, then $\mathrm{A}$ and $\mathrm{C}$ are connected. Column (5) only considers as a cluster the pair of industries with more relative flows between each other. See Section 4 for more details. 


\section{Table A3. Effects of the Log of the MW Interacted with the HHI and Low Mobility on the Log of Teenage Employment (HHI Calculated Only for Teenage Workers)}

\begin{tabular}{lccccc}
\hline & $(1)$ & $(2)$ & $(3)$ & $(4)$ & $(5)$ \\
Dependent Variable: Ln (Teen Emp) & Hybrid & Low Mobility & NAICS & All Nodes & Top Pairs \\
\hline \multirow{2}{*}{ Ln (MW) } & & & & & \\
& $-0.223^{* *}$ & -0.167 & $-0.188^{*}$ & $-0.165^{*}$ & $-0.543^{* * *}$ \\
Monopsony Variable (HHI or LM) & $(0.0938)$ & $(0.138)$ & $(0.0944)$ & $(0.0928)$ & $(0.124)$ \\
& $-0.381^{* * *}$ & $-0.859^{* * *}$ & $-0.241^{* *}$ & -0.349 & $-1.173^{* * *}$ \\
Monopsony x Ln (MW) & $(0.138)$ & $(0.242)$ & $(0.106)$ & $(0.228)$ & $(0.342)$ \\
& $0.223^{* * *}$ & $0.447 * * *$ & $0.126^{* *}$ & 0.196 & $0.631^{* * *}$ \\
Constant & $(0.0757)$ & $(0.127)$ & $(0.0558)$ & $(0.122)$ & $(0.184)$ \\
& -0.494 & -1.806 & -0.416 & -0.577 & -0.0139 \\
& $(0.723)$ & $(1.539)$ & $(0.750)$ & $(0.740)$ & $(0.727)$ \\
Observations & & & & & \\
R-squared & 195,205 & 18,121 & 195,205 & 195,205 & 199,123 \\
\hline
\end{tabular}

Robust clustered standard errors in parentheses by states.

$* * * \mathrm{p}<0.01, * * \mathrm{p}<0.05, * \mathrm{p}<0.1$

Notes: All specifications include two-way fixed effects (county and time). Control variables are the log of the total population, log of teenage employment, and log of total private-sector employment. HHI measures concentration: $\mathrm{HHI}=0$ implies perfect competition, and $\mathrm{HHI}=1$ implies full concentration. Column (1) defines the labor market as clusters of industries, which consists of keeping only connections or links between industries with more relative flows of workers (top three links with highest flows with more than $90^{\text {th }}$ percentile of relative flows between industries). Column (2) uses low mobility, which measures the percentage of workers who, when they change jobs, do not change industries. Column (3) defines the labor market by 3-digit NAICS code. In column (4), the cluster is defined by all the links; for instance, if industry $\mathrm{A}$ is connected to industry $\mathrm{B}$, and industry $\mathrm{B}$ is connected to industry $\mathrm{C}$, then $\mathrm{A}$ and $\mathrm{C}$ are connected. Column (5) only considers as a cluster the pair of industries with more relative flows between each other. See Section 4 for more details. 
Table A4. Effects of the Log of the MW Interacted with the Low Mobility on the Log of Teenage Employment (Low Mobility using Workers that Moved to Other County)

(1)

Dependent Variable: Ln (Teen Emp) Low Mobility

\begin{tabular}{lc} 
Monopsony Variable (HHI or LM) & $-0.968^{* * *}$ \\
& $(0.275)$ \\
Monopsony x Ln (MW) & $0.503^{* * *}$ \\
& $(0.145)$ \\
& \\
Elasticity of the MW depending on Monopsony \\
Monopsony $=0$ & -0.184 \\
& $(0.158)$ \\
Monopsony $=0.2$ & -0.0843 \\
& $(0.161)$ \\
Monopsony $=0.4$ & 0.0158 \\
& $(0.169)$ \\
Monopsony $=0.6$ & 0.116 \\
& $(0.181)$ \\
Monopsony $=0.8$ & 0.216 \\
& $(0.197)$ \\
Monopsony $=1$ & 0.316 \\
Constant & $(0.215)$ \\
& -1.691 \\
Observations & $(1.761)$ \\
R-squared & \\
\hline
\end{tabular}

Robust clustered standard errors in parentheses by states.

*** $\mathrm{p}<0.01, * * \mathrm{p}<0.05, * \mathrm{p}<0.1$

Notes: All specifications include two-way fixed effects (county and time). Control variables are the log of the total population, log of teenage employment, and log of total private-sector employment. HHI measures concentration: $\mathrm{HHI}=0$ implies perfect competition, and $\mathrm{HHI}=1$ means full concentration. Low mobility, which measures the percentage of workers who, when they change jobs, do not change industries, it includes workers that moved to other counties. 
Table A5. Effects of the Log of the M.W Interacted with the HHI and Low Mobility on the Log of Prime-Age

\begin{tabular}{|c|c|c|c|c|c|}
\hline Dependent Variable: Ln (Prime Age Emp) & $\begin{array}{c}(1) \\
\text { HHI }\end{array}$ & $\begin{array}{c}(2) \\
\text { Low Mobility }\end{array}$ & $\begin{array}{c}\text { (3) } \\
\text { NAICS }\end{array}$ & $\begin{array}{c}(4) \\
\text { Flexible }\end{array}$ & $\begin{array}{c}(5) \\
\text { Top Pairs }\end{array}$ \\
\hline $\operatorname{Ln}(\mathrm{MW})$ & $\begin{array}{l}-0.0272 \\
(0.0866)\end{array}$ & $\begin{array}{c}0.139 \\
(0.113)\end{array}$ & $\begin{array}{c}0.0345 \\
(0.0797)\end{array}$ & $\begin{array}{c}-0.00485 \\
(0.0830)\end{array}$ & $\begin{array}{c}0.0400 \\
(0.0992)\end{array}$ \\
\hline $\mathrm{HHI}$ & $\begin{array}{c}0.149 \\
(0.296)\end{array}$ & & $\begin{array}{c}0.317 \\
(0.286)\end{array}$ & $\begin{array}{c}0.199 \\
(0.290)\end{array}$ & $\begin{array}{c}0.389 \\
(0.322)\end{array}$ \\
\hline HHI x Ln (MW) & $\begin{array}{l}0.0514 \\
(0.151)\end{array}$ & & $\begin{array}{c}-0.0572 \\
(0.141)\end{array}$ & $\begin{array}{l}0.0136 \\
(0.148)\end{array}$ & $\begin{array}{c}-0.0601 \\
(0.160)\end{array}$ \\
\hline Low Mobility & & $\begin{array}{c}0.452 \\
(0.368)\end{array}$ & & & \\
\hline Low Mobility x Ln (MW) & & $\begin{array}{l}-0.220 \\
(0.186)\end{array}$ & & & \\
\hline Constant & $\begin{array}{c}0.960 \\
(0.672)\end{array}$ & $\begin{array}{c}2.732^{* * *} \\
(0.602)\end{array}$ & $\begin{array}{c}0.897 \\
(0.678)\end{array}$ & $\begin{array}{c}0.930 \\
(0.683)\end{array}$ & $\begin{array}{c}0.828 \\
(0.665)\end{array}$ \\
\hline Observations & 204,984 & 18,130 & 204,984 & 204,984 & 204,984 \\
\hline R-squared & 0.999 & 0.999 & 0.999 & 0.999 & 0.999 \\
\hline
\end{tabular}

Robust clustered standard errors in parentheses by states.

${ }^{* * *} \mathrm{p}<0.01,{ }^{* *} \mathrm{p}<0.05,{ }^{*} \mathrm{p}<0.1$

Notes: All specifications include two-way fixed effects (county and time). Control variables are the log of the total population, $\log$ of prime-age employment, and $\log$ of total private-sector employment. HHI measures concentration: $\mathrm{HHI}=0$ implies perfect competition, and $\mathrm{HHI}=1$ implies full concentration. Column (1) defines the labor market as clusters of industries, which consists of keeping only connections or links between industries with more relative flows of workers (top three links with highest flows with more than $90^{\text {th }}$ percentile of relative flows between industries). Column (2) uses low mobility, which measures the percentage of workers who, when they change jobs, do not change industries. Column (3) defines the labor market by 3-digit NAICS code. In column (4), the cluster is defined by all the links; for instance, if industry A is connected to industry B, and industry B is connected to industry C, then A and C are connected. Column (5) only considers as a cluster the pair of industries with more relative flows between each other. See Section 4 for more details. 


\section{Appendix B: Clusters Classifications}

I follow four criteria to calculate the industry clusters:

1. HHI (Preferred Classification): The rule followed is that I only use the top three connections for each industry (i.e. one industry with another three) or any other industry with at least in the $90^{\text {th }}$ of the relative flows to capture important connections. For instance, the industry 4239 (Miscellaneous Durable Goods Merchant Wholesalers) has more flows with 562 (Waste Management and Remediation Services), 2213 (Water, Sewage and Other Systems), and 2123 (Nonmetallic Mineral Mining and Quarrying). However, there are many flows with other industries as well, such as with the industry 4219 (Miscellaneous Durable Goods Wholesalers). Thus, in these cases, I added more industries to the cluster until the next candidate has less than the value $90^{\text {th }}$ of relative flow. In Figure 1, the red link is the stronger connection, green links are medium, and the yellow ones are weak. One cluster is formed by all the industries connected by the sum of green and red links. The hybrid cluster includes 421 and the top three connections 4413, 4411, and 4213. In some cases, clusters in this classification have more than four industries (one has up to 148), and others have fewer (one has two industries). Using this classification results in nine clusters of industries. This is my preferred classification because it is a compromise between all four.

2. NAICS: I assume that a worker can only work in the same industry (defined by the NAICS code). This assumption is the most restrictive, because workers cannot move among different industries; it is included for robustness and to present the extreme case where workers are stuck in one industry.

3. Flexible: For the calculation of criteria 2, 3, and 4, I create a web of industries connected by links. I need to restrict the number of flows to define a link because if I use a small number of flows, all the industries became one whole cluster. I define a link as more 
than the mean of flows of workers $(75.25 \text { flows })^{19}$ between industries in the whole period and all counties. Once a link is defined, I allow that all the industries connected by a link become one cluster. In Figure 1, this classification includes all the industries that are connected in the figure (sum of yellow, green, and red links), even if the connection is not direct, such as 722 and 4211, which are connected through 3327; or consider 4213, which is connected to 6241 via 4221 . Using this classification leads to only two clusters: one with 215 industries and the other with only two industries: Iron and Steel Mills and Ferroalloy Manufacturing, and Metal and Mineral (except Petroleum) Merchant Wholesalers.

4. Top Pairs: This method includes only the pair of industries with a stronger connection, that is, a greater number of flows between each other. Industry 4411 (Automobile Dealers) has a greater flow of workers with industry 4413 (Automotive Parts, Accessories, and Tire Stores) than with any other industry. Hence, 4411 and 4413 have a reliable connection, and they form a cluster. In Figure 1, it is represented with a red node. Using this classification results in 60 clusters of two industries each.

Note that not all the industries are in a cluster. If one industry has less than the mean of relative flows, it is not considered to be part of any cluster. A final remark is that CPS industry codes are different from NAICS. I use the official Census "Industry Code Crosswalk" to transform the codes from CPS to NAICS.

\footnotetext{
${ }^{19}$ I try different cutoffs for the number of flows. If I consider nodes with fewer than 50 flows, it results in one cluster of industries (all the industries are connected). Hence, using the mean of flows can be interpreted as the minimum number of flows needed to have at least two clusters of industries.
} 